\title{
Broccoli or Sulforaphane: Is It the Source or Dose That Matters?
}

\author{
Yoko Yagishita ${ }^{1}$, Jed W. Fahey ${ }^{2,3,4}$, Albena T. Dinkova-Kostova ${ }^{3,4,5}$ and Thomas W. Kensler ${ }^{1,4, *}$ \\ 1 Translational Research Program, Fred Hutchinson Cancer Research Center, Seattle, WA 98109, USA; \\ yyagishi@fredhutch.org \\ 2 Department of Medicine, Division of Clinical Pharmacology, Johns Hopkins School of Medicine, \\ Baltimore, MD 21205, USA; jfahey@jhmi.edu \\ 3 Department of Pharmacology and Molecular Sciences, Johns Hopkins School of Medicine, \\ Baltimore, MD 21205, USA \\ 4 Cullman Chemoprotection Center, Johns Hopkins School of Medicine, Baltimore, MD 21205, USA \\ 5 Jacqui Wood Cancer Centre, Division of Cellular Medicine, Ninewells Hospital and Medical School, \\ University of Dundee, Dundee DD1 9SY, Scotland DD1 9SY, UK; A.DinkovaKostova@dundee.ac.uk \\ * Correspondence: tkensler@fredhutch.org; Tel.: +1-206-667-6005
}

Academic Editor: Gary D. Stoner

Received: 24 September 2019; Accepted: 2 October 2019; Published: 6 October 2019

\begin{abstract}
There is robust epidemiological evidence for the beneficial effects of broccoli consumption on health, many of them clearly mediated by the isothiocyanate sulforaphane. Present in the plant as its precursor, glucoraphanin, sulforaphane is formed through the actions of myrosinase, a $\beta$-thioglucosidase present in either the plant tissue or the mammalian microbiome. Since first isolated from broccoli and demonstrated to have cancer chemoprotective properties in rats in the early 1990s, over 3000 publications have described its efficacy in rodent disease models, underlying mechanisms of action or, to date, over 50 clinical trials examining pharmacokinetics, pharmacodynamics and disease mitigation. This review evaluates the current state of knowledge regarding the relationships between formulation (e.g., plants, sprouts, beverages, supplements), bioavailability and efficacy, and the doses of glucoraphanin and/or sulforaphane that have been used in pre-clinical and clinical studies. We pay special attention to the challenges for better integration of animal model and clinical studies, particularly with regard to selection of dose and route of administration. More effort is required to elucidate underlying mechanisms of action and to develop and validate biomarkers of pharmacodynamic action in humans. A sobering lesson is that changes in approach will be required to implement a public health paradigm for dispensing benefit across all spectrums of the global population.
\end{abstract}

Keywords: broccoli; sulforaphane; glucoraphanin; myrosinase; chemoprotection; allometric scaling; clinical trials; Nrf2; toxicity

\section{Introduction}

\subsection{Epidemiology of Broccoli and Health}

The collective retrospective (observational), prospective, and interventional evidence for the beneficial effects of broccoli on health is robust. The former two categories will be briefly summarized herein, and the latter make up the bulk of this review. Broccoli was thought to have been domesticated in the 1500s, brought to the UK in the early 1700s, and to the future United States in the late 1700s, but was little-known in the USA until the 1920s [1]. Thus, as a relatively new crop, one can only point to about a century of relatively widespread consumption. The epidemiology of broccoli's impact on health covers precisely half of that century, beginning with Graham's early work showing a dose-response 
relationship between the consumption of broccoli and other cruciferous vegetables, on colon cancer [2]. Since then there have been impressive demonstrations of risk reduction associated with cruciferous vegetables and/or broccoli for bladder cancer [3] and prostate cancer [4] just to name a few. We and others have recently reviewed the growing body of epidemiologic and mechanistic work implicating cruciferous vegetables in general, broccoli specifically, and sulforaphane, with respect to its association with neurologic, neoplastic, dermatologic, and other conditions (e.g., [5-9]). Organizations including the World Cancer Research Fund and the American Institute for Cancer Research have chosen to highlight lifestyles (a Mediterranean type diet) and food groups (non-starchy vegetables or fruit) as featuring strongly in cancer prevention, and they have moved away from recommending specific fruits or vegetables vis à vis cancer risk [10]. However, all evidence points to broccoli and more specifically to sulforaphane from broccoli, and its biogenic precursor glucoraphanin, as being protective against a variety of chronic, and even infectious (e.g., Helicobacter pylori) conditions [11].

\subsection{Discovery of Sulforaphane as a Bioactive Isothiocyanate}

Sulforaphane was described in the middle of the last century, as an antibiotic, and was isolated from red cabbage, and from the western USA rangeland weed hoary cress [12]. Various groups have since synthesized it, but Talalay and Zhang were the first to isolate it from broccoli [13] and to demonstrate its cancer protective properties [14]. Its biogenic precursor, glucoraphanin, was then found in abundance in broccoli sprouts and sulforaphane was confirmed to be active in animal carcinogenesis models [15]. Structure-activity evaluation of a series of over 100 synthetic analogs made by Posner and colleagues did not find a more potent inducer of cytoprotective (Phase 2) enzymes than sulforaphane [16], and indeedeme sulforaphane remains one of, if not, the most potent naturally occurring inducers yet discovered [17]. We and many others have identified subsequently multiple pathways and metabolic consequences of this molecule's presence in mammalian cells, tissues, and in the human body $[8,18,19]$. While far too numerous to review herein, we note this multiplicity of effects has been well reviewed by others [20-22]. Our early work showed that in the undamaged plant there is very little if any free sulforaphane, all of it being present in the form of its biologically inactive precursor glucoraphanin [15]. Thus, it is important to consider the factors controlling glucoraphanin biosynthesis in plants.

\subsection{Biosynthesis and Function of Glucoraphanin in Broccoli}

The glucosinolate glucoraphanin is derived from the amino acid methionine. The biosynthetic pathway leading to glucoraphanin formation in natura is elaborate and includes three separate stages (Scheme 1) $[23,24]$. The first stage results in the elongation of the methionine side chain by two methylene groups. The second stage forms the core glucosinolate structure. The third stage constitutes a secondary modification of the glucosinolate side chain.

During the first stage (Scheme 1a), a cytoplasmic branched chain amino acid aminotransferase (BCAT) catalyzes the transamination of methionine to give 2-oxo-4-methylthiobutanoic acid. In turn, this $\alpha$-keto acid is elongated by two methylene groups in a cyclical mechanism which involves two rounds of three successive transformations that take place in the chloroplast: (i) a condensation with acetyl-CoA, which is catalyzed by a methylthioalkyl malate synthase (MAM); (ii) an isomerization catalyzed by aconitase (AC); (iii) an oxidative decarboxylation catalyzed by an isopropylmalate dehydrogenase (IPMDH). The final product of these transformations, 2-oxo-6-methylthiohexanoic acid, is converted to dihomomethionine in a transamination reaction catalyzed by a BCAT.

During the second stage (Scheme 1b), dihomomethionine undergoes a cytochrome P450 (CYP)-mediated conversion to an aldoxime, which is then further oxidized to a nitrile oxide and subsequently conjugated to a sulfur donor, such as glutathione (GSH). The conjugation reaction can occur non-enzymatically or can be catalyzed by a glutathione S-transferase. The resulting S-alkyl-thiohydroxymate is converted to a thiohydroxymate in a reaction catalyzed by the C-S lyase SUR1. 


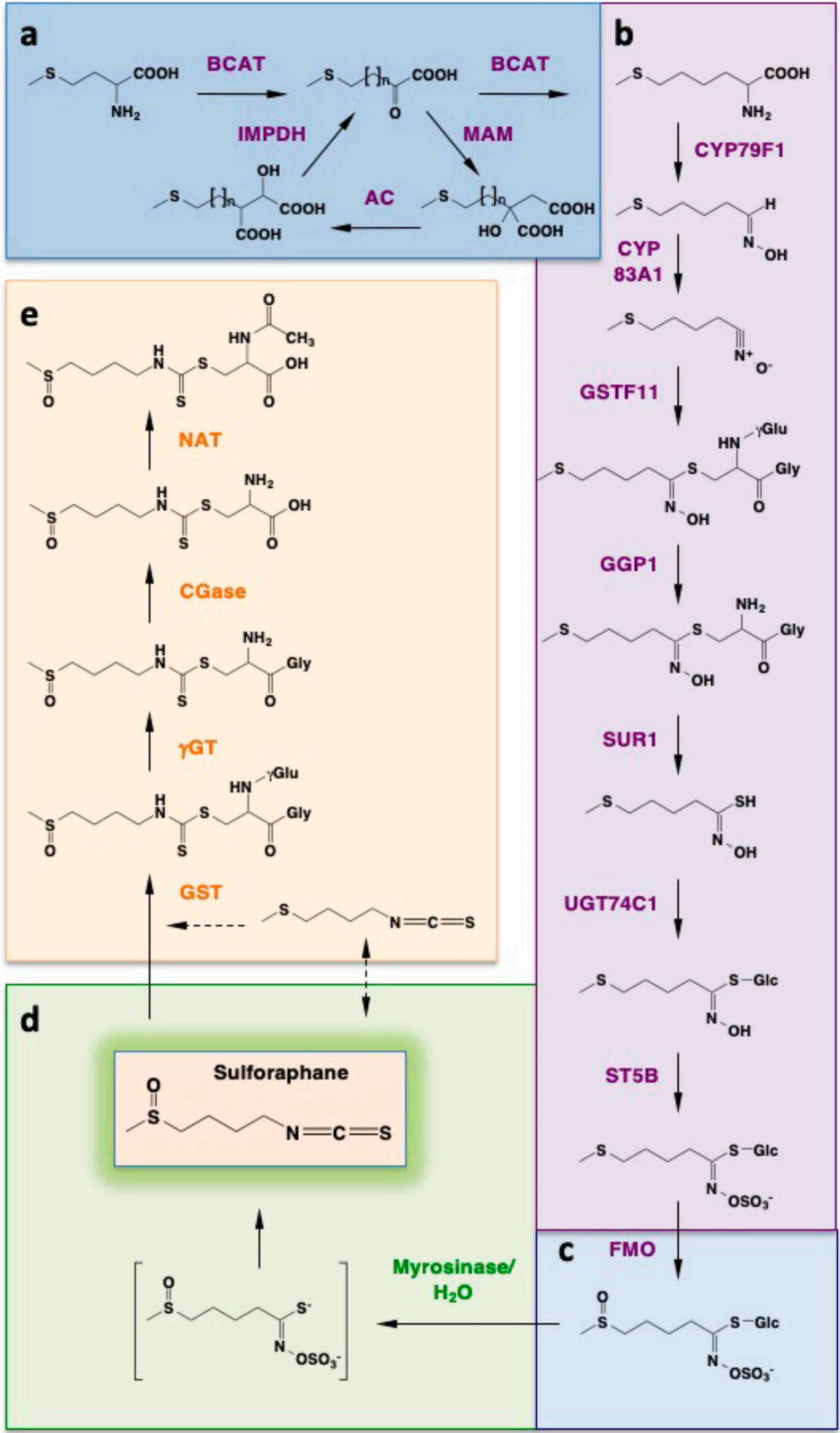

Scheme 1. Biosynthesis of glucoraphanin, its hydrolysis to form the isothiocyanate sulforaphane, and metabolism of sulforaphane. The highly reactive isothiocyanate sulforaphane is produced in plants as an inert precursor, the glucosinolate glucoraphanin. Its biosynthetic pathway originates from the amino acid methionine and proceeds in three stages: (i) methionine side chain elongation by two methylene groups (a); (ii) formation of the core glucosinolate structure (b); (iii) secondary modification of the glucosinolate side chain (c); Upon disruption of the plant tissue integrity, glucoraphanin comes into contact with myrosinase, which catalyzes the hydrolysis of glucoraphanin to give sulforaphane (d); In mammalian cells, sulforaphane is metabolized through the mercapturic acid pathway, and can also undergo an interconversion to erucin (e). 
Because this enzyme requires a free amino group within the substrate, an intermediate step is required: The hydrolytic removal of the $\gamma$-glutamyl residue within the conjugate between glutathione and the activated aldoxime, a reaction catalyzed by $\gamma$-glutamyl peptidase (GGP). The last steps of the second stage are a glucosyltransferase-mediated S-glucosylation resulting is the formation of a desulfoglucosinolate, followed by sulfation catalyzed by a sulfotransferase (ST). Thus, the parent glucosinolate, 4-methylthiobutyl glucosinolate (glucoerucin) is produced.

During the final stage (Scheme 1c), a secondary modification of the glucosinolate side chain occurs. This is accomplished by an S-oxygenation reaction, which is catalyzed by a flavin monooxygenase (FMO). Together, these elaborate biotransformations, which involve 13 enzymes, result in the synthesis of glucoraphanin. Notably, in Arabidopsis the biosynthesis of glucosinolates is regulated by light (being downregulated in prolonged periods of darkness and greatly increased following exposure to light) and shows diurnal variations that are coordinated with those of general sulfur metabolism [25].

Glucoraphanin is chemically stable and biologically inert. However, following plant tissue injury, such as biting or chewing, glucoraphanin comes in contact with the enzyme myrosinase, a B-thioglucosidase, which in the intact plant is physically separated from its substrate. Myrosinase catalyzes the hydrolysis of glucoraphanin to liberate glucose and form an unstable aglucone (Scheme 1d) that spontaneously rearranges to give rise to a range of products, the most reactive of which is the isothiocyanate sulforaphane. Importantly, mammalian cells do not produce myrosinases; however, the conversion of glucoraphanin to sulforaphane still occurs in mammals. It is carried out by the bacterial microflora of the gastrointestinal tract and can be greatly reduced by antibiotic treatment or mechanical bowel cleansing [26]. Of note, this microbially-mediated conversion of glucoraphanin has been exploited in a recent study to generate high concentrations of sulforaphane locally in the colon of mice [27].

In plants, the main function of the glucosinolates is considered to be defense against pathogens and herbivores, and this has largely been attributed to the isothiocyanate hydrolytic products. Resistance to pathogens positively correlates with the glucosinolate content of the plant [28], which also affects the fungal species composition in the soil [29]. In addition, there is a correlation between alterations in the glucosinolate profile of the plant and basic physiological processes, such as photosynthesis and growth, that occur during abiotic stress, including drought, extreme temperatures, light, salinity, and nutrient deprivation [30]. Taken together, these correlations suggest that the glucosinolates function for protection of the plant against a wide array of environmental challenges. It is therefore not surprising that domesticated lines of Brassica oleracea have lower glucosinolate levels compared to wild species [31]; conversely, the glucoraphanin content of certain wild Brassica species (B. villosa) is high, and this species has been used to generate broccoli hybrids with enhanced concentrations of glucoraphanin [32]. In addition to their role in plant defense, high levels of isothiocyanates have been shown to reduce the biomass of the plant, and interestingly, mutants deficient in glutathione biosynthesis are more susceptible than their wild-type counterparts to the growth-inhibitory effect sulforaphane [33], suggesting similarities in sulforaphane metabolism in plants and mammals.

\subsection{Glucoraphanin Levels in Broccoli}

Glucoraphanin occurs in all tissues of broccoli plants, though it is most abundant in the aerial portions and the developing florets (flower buds) and ultimately the seeds, are richest in this compound (Figure 1). Although two or three other edible cruciferous (Brassica) species contain significant amounts of glucoraphanin, it is not as widespread as popular culture would have it. In one sampling of 31 fresh, uncooked broccoli (Brassica oleracea var. italica) heads, each from different Baltimore area supermarkets, we found a mean of $0.38 \mu \mathrm{mol}$ glucoraphanin per gram fresh weight, but with a range of from less than 0.005 to $1.13 \mu \mathrm{mol} / \mathrm{gram}$ [34]. Levels of glucoraphanin when tested in over 75 different genotypes of field-grown hybrid broccoli averaged 0.88 and $1.10 \mu$ mol glucoraphanin per gram fresh weight when grown in the same fields in two consecutive years [35]. Further work with 32 different genotypes grown across three different years, in the field and the greenhouse produced a similar range of values and a 
mean glucoraphanin content in broccoli heads of $0.36 \mu \mathrm{mol}$ per gram fresh weight [36]. Glucoraphanin level in broccoli seeds was judged to be largely determined by genotype, though the environment in which the plants are grown (e.g., location, year, drought, pollution, and disease pressure) also plays a clear and significant role [37].

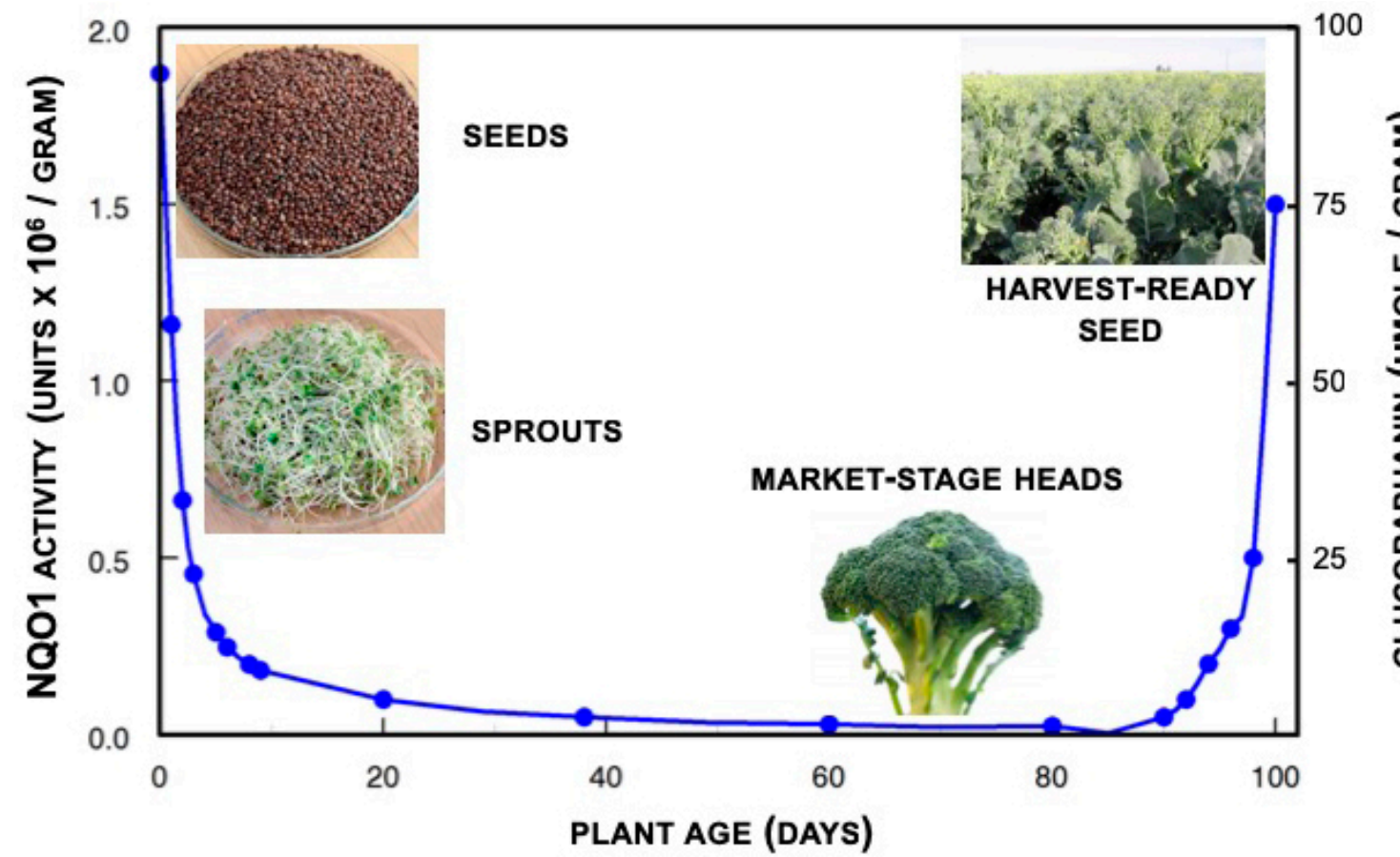

Figure 1. On a weight basis, glucoraphanin (right axis) is most abundant in the seeds of the broccoli plant. Upon enzymatic conversion to sulforaphane, the capacity of extracts of these plants to induce or up-regulate phase 2 enzymes such as NQO1 in mammalian cells, follows precisely the same curve (left axis).

\section{Broccoli-Based Intervention in Rodents}

\subsection{Formulation, Route of Administration and Dose}

We surveyed the now vast literature on the evaluation of sulforaphane as an agent for disease prevention in mouse and rat models. While some studies reported feeding animals with broccoli (typically lyophilized) incorporated into rodent diets, the large majority have examined efficacy (monitored through molecular, biochemical, biological or pathological endpoints) of sulforaphane as a discrete, commercially available research-grade chemical. Of note, while $R$-sulforaphane is found naturally, the synthetically derived $R, S$-sulforaphane has been likely used in most animal studies due to historical matters of availability and relative cost. Most publications do not directly account for the form of sulforaphane used. There is some suggestion that $R$-sulforaphane shows increased effectiveness compared to its racemic $R, S$ counterpart in various models. This review focuses on animal studies using sulforaphane as the test article as few of the dietary studies with broccoli-based preparations attempted to accurately determine the administered bioactive dose.

Animal studies have principally used three routes of administration for sulforaphane: Oral, intraperitoneal and topical. Figure 2 highlights the distributions of doses selected by investigators for oral or intraperitoneal dosing to mice. Oral administration is the route typically used by the NCI in chemopreventive agent development [39]. Yet, somewhat paradoxically as depicted in Figure 2, intraperitoneal administration has been the most commonly employed route for studies with sulforaphane. Presumably this choice reflects relative ease of administration to animals rather than 
attempted mimicry of a route most appropriate for administration of a dietary compound or matrix to humans.
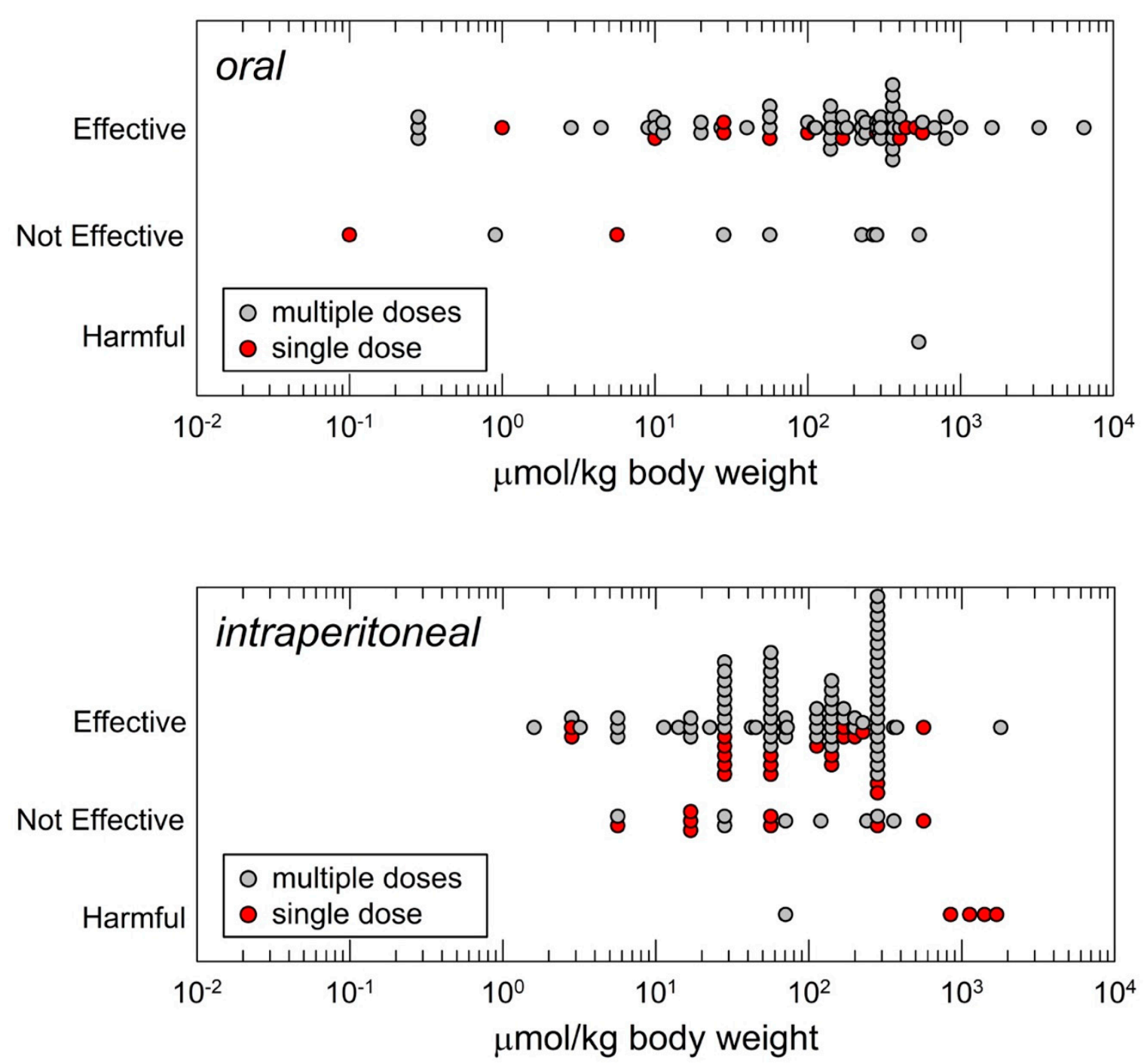

Figure 2. Distribution of daily doses of sulforaphane administered to mice as reported in the literature based on route of administration and efficacy outcome. Top panel, oral (gavage or in diet); bottom panel, intraperitoneal administration. Where necessary, dose extrapolations assumed $25 \mathrm{~g}$ body weight and dietary intake of $4 \mathrm{~g}$ food/mouse/day [38].

That said, dose ranges for intraperitoneal administration appears to provide roughly equivalent pharmacological efficacy to oral dosing with sulforaphane, presumably reflecting the excellent bioavailability of this agent. Doses selected for oral administration have spanned a greater than 4-log range and those for intraperitoneal administration an overlapping 3-log range. The median effective dose of sulforaphane in the published literature by oral administration is $175 \mu \mathrm{mol} / \mathrm{kg}$ body weight and by intraperitoneal administration is $113 \mu \mathrm{mol} / \mathrm{kg}$. Likely reflecting publication bias, most studies irrespective of route of administration report a positive outcome on efficacy. Nonetheless, also informative, is the observation that studies, albeit far fewer in number, report a lack of efficacy in some models: E.g., tumor xenografts or chemical carcinogenesis, bacterial infections, airways inflammation and cerebral ischemia. For most of the listed "not effective" responses, significant responses were reported for study endpoints at higher doses as part of dose-response evaluations. Very few studies report harmful outcomes but are notable as discussed later. Topical application of 
sulforaphane has been used effectively in limited settings for mitigation of skin erythema, inflammation or photocarcinogenesis.

The literature surveyed is listed and annotated for studies employing oral (Table S1), intraperitoneal (Table S2), and topical (Table S3) administration of sulforaphane to mice as well as oral administration to rats (Table S4).

\subsection{Efficacy Endpoints: Mechanisms Versus Dose, Risks and Benefits}

Relatively few studies have rigorously examined the mechanisms of action in vivo of sulforaphane that underlie the reported biological outcomes (Figure 3). This experimental paucity lies in stark contrast to the multitude of studies reporting on mechanistic actions identified in cell culture systems as reviewed elsewhere $[40,41]$. A recent bibliometric review indicates that sulforaphane is the most cited natural product activator of Nrf2 signaling [42]. Indeed, several studies have compared the action of sulforaphane on Nrf2 signaling and disease prevention by comparing outcomes in wild-type and Nrf2-knockout mice. In several cases, Nrf2-dependent effects have been linked to anti-inflammatory actions. In both settings (with some overlapping studies), a wide range of doses have been employed, indicating at least lower bounds for efficacy $(3-10 \mu \mathrm{mol} / \mathrm{kg})$. Studies examining the induction of apoptosis in vivo, principally in xenograft anti-tumorigenesis experiments have utilized high doses $(>60 \mu \mathrm{mol} / \mathrm{kg})$. A similar reliance on higher doses is reflected in studies on the inhibition of histone deacetylase (HDAC) activities $(>100 \mu \mathrm{mol} / \mathrm{kg})$. Absence of data in these cases should be distinguished from absence of effect at lower doses. Further experiments are required. To this point, relatively few dose-response studies have been conducted in vivo, so it is not possible to appreciate whether a plot of the relationship of response(s) to sulforaphane dose may take the form of " $S$ ", " $\cap$ " or possibly some other shape. No maximally effective doses have been established-They are likely to vary depending upon the endpoint.

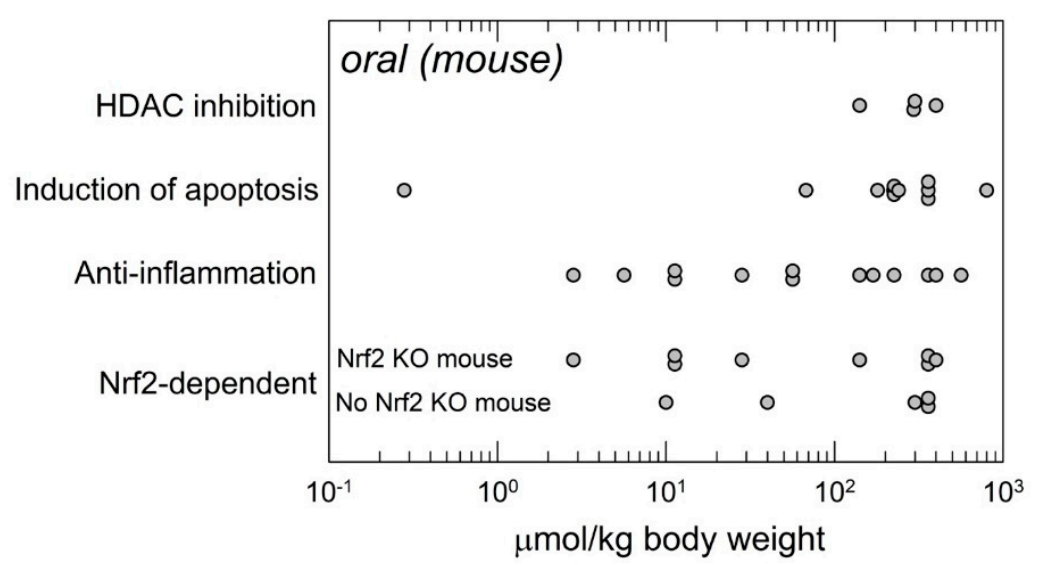

Figure 3. Distribution of oral doses of sulforaphane administered to mice in studies that included experimental examination of underlying mechanisms in vivo. Data are as reported and interpreted in the original publications. Listed mechanisms are not necessarily exclusive. Nrf2 KO: Nrf2 knockout. Some studies included comparisons of responses in wild-type and Nrf2 KO mice to impute Nrf2-dependence and are also included in the listed mechanisms (primarily "anti-inflammation").

Several studies conducted with higher doses of sulforaphane in mice do describe toxicities that require careful attention to risk-benefit analyses and determination of therapeutic or prophylactic indices. Socala et al. [43] examined the toxicity profile of sulforaphane in mice after intraperitoneal injection of single doses. High doses of sulforaphane produced marked sedation (at 150-300 mg/kg), hypothermia (at 150-300 mg/kg), impairment of motor coordination (at 200-300 mg/kg), decrease in skeletal muscle strength (at 250-300 mg/kg), and deaths (at 200-300 mg/kg). The LD 50 value of sulforaphane in mice was estimated to be $213 \mathrm{mg} / \mathrm{kg}$ i.p. (1203 $\mu \mathrm{mol} / \mathrm{kg})$. This value is about 10-fold higher than the median dose reported for efficacy outcomes in mice. Sulforaphane (at $100 \mathrm{mg} / \mathrm{kg}$ ) 
potentiated the anticonvulsant efficacy of carbamazepine in a seizure test. This drug interaction could have been pharmacokinetic in nature, a form of interaction also considered but not observed in humans [44]. Shorey et al. [45] observed increased morbidity and no reduction in lung tumorigenesis in offspring born to mothers receiving transplacental and lactational exposure to the carcinogen dibenzo[def,p]chrysene and supplemented with dietary sulforaphane (400 ppm) or its primary whole food source, broccoli sprouts $(10 \% w \mathrm{t} / w \mathrm{t})$, contrasting to many reports of chemoprotection in adult animal models. Of potentially greatest concern is the study of Tao et al. [46]. They utilized a chemical carcinogenesis model with vinyl carbamate (A/J mice) and a genetic model (LSL-K-rasG12D/+ mice) to induce lung cancers. Mice were treated intraperitoneally with $12.5 \mathrm{mg} / \mathrm{kg}(75.5 \mu \mathrm{mol} / \mathrm{kg})(5 \mathrm{doses}$, once every three days during tumor induction (pre-treatment) or $12.5 \mathrm{mg} / \mathrm{kg}$ every three days, starting one week after tumor induction for 13 weeks (post-treatment). In the chemical carcinogenesis model, pre-treatment reduced the number of tumors, and post-treatment slightly promoted tumors. In the genetic model, pre-treatment with SF had no effect on tumor number, but post-treatment increased tumor number and size. Given observed efficacy in humans at doses $<0.5 \mu \mathrm{mol} / \mathrm{kg}$ of sulforaphane, and providing allowance for allometric scaling from mice and the improved bioavailability with i.p. dosing, there is only a 10-fold difference in safety margin. It should be noted that Kombairaju et al. [47] reported that prolonged sulforaphane treatment $(0.5 \mathrm{mg}, 5 \mathrm{~d} / \mathrm{wk}$ for $3 \mathrm{mo}$. by means of a nebulizer $)$ did not enhance tumorigenesis in the same LSL-K-rasG12D/+ mouse model. In settings of long-term preventive interventions with sulforaphane or a broccoli-based formulation, careful consideration will need to be given to matters of dose, schedule and duration.

\section{Broccoli-Based Clinical Trials}

\subsection{Sulforaphane Pharmacokinetics and Pharmacodynamics}

Upon entry into the mammalian cell, sulforaphane is conjugated with GSH in a GST-catalyzed reaction, entering the mercapturic acid pathway (Scheme 1e). The glutathione conjugate of sulforaphane is subjected to a series of sequential conversions catalyzed by $\gamma$-glutamyltranspeptidase $(\gamma \mathrm{GT})$, followed by cysteinylglycinase (CGase), and N-acetyltransferase (NAT). The final product is the $\mathrm{N}$-acetylcysteine conjugate of sulforaphane (mercapturic acid). In addition, sulforaphane can undergo an interconversion to erucin [1-isothiocyanato-4-(methylthio)butane], which is then metabolized in an identical manner to that for sulforaphane [48,49].

Sulforaphane and its metabolites (dithiocarbamates) can be quantified collectively by cyclocondensation with 1,2-benzenedithiol, with sensitivity in the picomolar range [50]. This highly sensitive, simple and convenient method has been widely used to measure the levels of sulforaphane and its metabolites in blood, plasma, urine and tissues following sulforaphane administration to rodents and humans. The use of this method revealed that sulforaphane crosses the placental barrier based on detection of dithiocarbamates in embryos $2 \mathrm{~h}$ post-treatment of pregnant mice with a single $(5 \mu \mathrm{mol})$ dose of sulforaphane [51]. In addition, methods have been developed to analyze the individual metabolites following their separation by liquid chromatography coupled with tandem mass spectrometry (LC-MS/MS) [52,53]. Furthermore, the use of mass spectrometry coupled with stable isotope-labeled internal standards of sulforaphane [1-isothiocyanato-4-methyl-sulfinyl $\left(1,1,2,2,3,3,4,4-^{2} H 8\right)$ butane] and its corresponding mercapturic acid pathway conjugates allows for quantitative, precise, sensitive, and specific analysis of sulforaphane and its metabolites [54].

With these analytical tools in hand, a number of pharmacokinetic studies have been conducted in rodents and humans. Thus, following oral administration of an exceedingly high dose of $150 \mu \mathrm{mol}$ sulforaphane to 10-week-old female Sprague-Dawley rats, the concentration of dithiocarbamates in the plasma of the animals increased rapidly reaching a peak $\left(C_{\max }\right)$ of $60 \mu \mathrm{M} 1 \mathrm{~h}$ after dosing, with area under the concentration curve (AUC) of $491 \mathrm{~h} \mu \mathrm{mol} / \mathrm{L}$, elimination constant $\left(K_{\mathrm{el}}\right)$ of $0.1 \mathrm{~h}^{-1}$, and elimination half-life of $6.7 \mathrm{~h}$ [55]. Similarly, following oral administration of $200 \mu \mathrm{mol}$ broccoli sprout isothiocyanates to four healthy human volunteers, the peak plasma dithiocarbamate 
concentration $\left(C_{\max }\right)$ was $1.91 \pm 0.24(0.943-2.27) \mu \mathrm{M} 1 \mathrm{~h}$ after dosing, with half-life of $1.77 \pm 0.13 \mathrm{~h}$, and clearance of $369 \pm 53 \mathrm{~mL} / \mathrm{min}$ [56]. A study in 20 participants administered $200 \mu \mathrm{mol}$ sulforaphane as sulforaphane-rich powder in capsules reported a $C_{\max }$ of $0.7 \pm 0.2 \mu \mathrm{M}$ at $3 \mathrm{~h}$, with a half-life of $1.9 \pm 0.4 \mathrm{~h}$ for elimination of sulforaphane equivalents measured by mass spectrometry [57]. Another pharmacokinetic study, in which a single dose of broccoli soup delivering the equivalent of either $16 \mu \mathrm{mol}$ or $52 \mu \mathrm{mol}$ of sulforaphane was administered, reported $C_{\max }$ of $2.2 \pm 0.8 \mu \mathrm{M}$ and $7.3 \pm 2.9 \mu \mathrm{M}$ at $1.5 \mathrm{~h}$ and $2 \mathrm{~h}$ for the low and the high dose, respectively [53]. A double-blinded, randomized crossover trial with broccoli soups (prepared from plants with increased glucoraphanin content) delivering a single dose of 84,280 , or $452 \mu \mathrm{mol}$ of glucoraphanin documented peak plasma concentrations $\left(C_{\max }\right)$ of $0.17 \pm 0.12,0.37 \pm 0.26$, and $0.61 \pm 0.40 \mu \mathrm{M}$, respectively [52]. Another study reported plasma dithiocarbamate levels of $0.92 \pm 0.72 \mu \mathrm{M}$ and mean epithelial-/stromal-enriched breast tissue dithiocarbamate concentration of $1.45 \pm 1.12$ and $2.00 \pm 1.95 \mathrm{pmol} / \mathrm{mg}$ tissue for the right and the left breast, respectively in eight healthy women undergoing reduction mammoplasty who had received a single dose of a broccoli sprout preparation delivering $200 \mu \mathrm{mol}$ sulforaphane $1 \mathrm{~h}$ prior to surgery [55].

In a double-blind randomized placebo-controlled trial in men presenting for prostate biopsy, plasma levels of $0.12 \mu \mathrm{M}$ of sulforaphane and its metabolites were detected after an intervention period of 4-8 weeks with two daily doses of $100 \mu \mathrm{mol}$ sulforaphane administered $12 \mathrm{~h}$ apart [58]. Isothiocyanate levels of $2.2 \mu \mathrm{M}$ and $500 \mathrm{nM}$ were detected in the plasma and synovial fluid, respectively of patients with osteoarthritis undergoing knee replacement surgery following consumption of glucosinolate-rich diets for 2 weeks [59].

A study in healthy subjects who received single oral doses of broccoli sprout extracts containing the equivalent of $111 \mu \mathrm{mol}$ of glucosinolates or isothiocyanates showed cumulative urinary dithiocarbamate excretion of $88.9 \pm 5.5 \mu \mathrm{mol}$ and $13.1 \pm 1.9 \mu \mathrm{mol}$ for the isothiocyanate and the glucosinolate preparation, respectively [60]. This study further revealed that for the isothiocyanate preparation, excretion was consistent and linear over a 25-200 $\mu$ mol dose range, whereas for the glucosinolate preparation, excretion was highly variable among individuals. These observations are in close agreement with results from a randomized, placebo-controlled, double-blind Phase I clinical trial, in which isothiocyanate $(25 \mu \mathrm{mol})$ or glucosinolate $(25 \mu \mathrm{mol}$ or $100 \mu \mathrm{mol})$-rich preparations were orally administered to three cohorts of three healthy human subjects at 8-h intervals for 7 days; one other subject in each cohort received placebo [61]. Notably, this study showed no evidence of clinically significant adverse events based on 32 types of hematology and chemistry tests, including liver (transaminases) and thyroid (TSH, T3, and T4) function tests. In agreement, a recent analysis of biochemical parameters of thyroid function in serum collected from 45 female volunteers that had participated in a randomized clinical trial revealed no alterations compared to baseline following an intervention for 12 weeks with a broccoli sprout beverage containing a combination of $40 \mu \mathrm{mol}$ sulforaphane and $600 \mu \mathrm{mol}$ of glucoraphanin [62].

The finding that compared to isothiocyanates, oral administration of glucosinolates results in lower bioavailability, slower elimination, and greater inter-individual variation in excretion was further strengthened by a larger (50 participants) crossover clinical trial that involved 5-day baseline period followed by daily administration of broccoli sprout beverages delivering either glucosinolates or their corresponding isothiocyanates for 7 days, 5-day washout period, and 7-day administration of the opposite intervention [63]. Using fecal sample collections from five subjects with high 24-h urinary excretion profiles ('high converters') and five subjects with low excretion profiles ('low converters'), it was found that ex vivo, the degradation of glucoraphanin was greater in cultures of fecal bacteria derived from the 'high converters' in comparison to the 'low converters' [64]. These observations are consistent with earlier work showing that mechanical cleansing or antibiotic treatment greatly reduce the glucosinolate conversion in healthy human subjects [26] and indicate that the gastrointestinal microflora represents a critical factor in determining the extent of gl ucosinolate hydrolysis. In addition to the inter-individual variations, there are also diurnal variations in the conversion of glucosinolates to dithiocarbamates, whereby conversion is greater during the day [65]. By contrast, the conversion of isothiocyanates to dithiocarbamates is higher during the night. 
Overall, in humans, sulforaphane is rapidly absorbed and eliminated with small inter-individual variations and typical urinary excretion of $70 \%$ to $90 \%$ of the dose. By contrast, the conversion of glucoraphanin is slow and with high inter-individual variations. The urinary excretion of sulforaphane metabolites following intervention with glucoraphanin-containing preparations typically range from $2 \%$ to $15 \%$ of the dose, being $1 \%$ to $45 \%$ at the extremes. The differences in inter-individual variations between sulforaphane and glucoraphanin make, at first glance, the use of sulforaphane much more attractive for the purposes of dose precision. However, in contrast to its stable glucosinolate precursor, sulforaphane is unstable, which has prompted the development of stabilized preparations, such as an $\alpha$-cyclodextrin-encapsulated form of sulforaphane [66] and a stabilized version of pure plant-derived sulforaphane, known as Prostaphane ${ }^{\circledR}$ (Nutrinov, Noyal sur Vilaine Cedex, France). Alternatively, glucoraphanin-rich preparations containing active myrosinase have also been used $[67,68]$. As formulations differ in their bioavailability (which provides a possible explanation for the differences in pharmacokinetic parameters reported in the various human studies), the excreted amount of sulforaphane metabolites in the urine, and not the amount in the administered preparation, provides a more reliable measure of the actual dose [69].

Similar to the studies of the pharmacokinetics of sulforaphane, nearly all human studies addressing the pharmacodynamics of sulforaphane have used glucoraphanin- or sulforaphane-rich broccoli-based preparations. Although there is currently no direct evidence for specific target engagement by sulforaphane in humans, there is clear evidence for its pharmacodynamic action. Thus, increased levels of the Nrf2-target enzymes A-class GSTs and NQO1 have been reported in plasma [70] and saliva [71] of human subjects consuming cruciferous vegetables. In agreement, administration of glucoraphanin/sulforaphane-rich preparations to healthy volunteers resulted in increased mRNA or protein levels of NQO1 and GSTs in PBMC, skin punch biopsies, as well as in nasal and buccal scrapings [72-76].

Broccoli-based glucoraphanin/sulforaphane-rich preparations have been shown to accelerate the detoxication and excretion of potentially carcinogenetic food contaminants and air pollutants, offering a very attractive strategy for population-wide reduction in cancer risk due to unavoidable exposures to pollution. A cross-over clinical trial with 50 human volunteers, which was conducted in Qidong, China, found statistically significant increases of $20-50 \%$ in the urinary excretion levels of glutathione-derived conjugates of the air pollutants acrolein and benzene following consumption of sulforaphane- and/or glucoraphanin-rich broccoli sprout-derived beverages [77]. A subsequent 12-week placebo-controlled, randomized clinical trial involving 291 participants from the same area using broccoli sprout beverages containing a combination of $40 \mu \mathrm{mol}$ sulforaphane and $600 \mu \mathrm{mol}$ glucoraphanin confirmed and extended these findings by showing that the excretion levels of the glutathione-derived conjugates of benzene and acrolein were significantly increased, by $61 \%$ and $23 \%$, respectively in the volunteers who received the broccoli sprout beverage compared with placebo [78]. Very recently, a randomized, placebo-controlled, multidose intervention trial of a broccoli sprout beverage, which was conducted in the same area of China, showed a dose-dependent excretion of the urinary metabolites of sulforaphane, and further found that a treatment regime with daily doses of $40 \mu \mathrm{mol}$ sulforaphane and $600 \mu \mathrm{mol}$ glucoraphanin for 10 days, resulting in an urinary excretion of $\sim 25 \mu \mathrm{mol}$ sulforaphane metabolites per day, promotes the detoxication of benzene [69].

Global gene expression profiling to evaluate the transcriptional changes in the prostate of men at high risk for prostate cancer has revealed that consumption of broccoli-rich diets for 6- or 12 months associates with transcriptional changes in signaling pathways involved in inflammation and carcinogenesis in the prostate tissue [79,80]; importantly, these changes are dose-dependently attenuated in subjects receiving the glucoraphanin-rich diet [80]. Other pharmacodynamic effects of interventions with glucoraphanin/sulforaphane in humans include: Increase in the levels of reduced glutathione in brain [81], enhanced integration of fatty acid $\beta$-oxidation with TCA cycle activity [82], protection against skin erythema caused by exposure to ultraviolet radiation $[83,84]$, reduction in plasma LDL-cholesterol [85], decrease in the levels of fasting blood glucose and glycated hemoglobin 
in obese patients with dysregulated type 2 diabetes [86], and improvements in social interaction, behavior, and verbal communication in young men with autism spectrum disorder [87]. Overall, although the precise molecular mediators are not always known, it is clear that interventions with glucoraphanin/sulforaphane-rich broccoli preparations in humans lead to diverse beneficial effects.

\subsection{Clinical Studies with Broccoli-Based Preparations: Efficacy}

Broccoli-based preparations consist almost exclusively of either glucoraphanin, sulforaphane, glucoraphanin with added active myrosinase, the raw, cooked, or dried vegetables themselves (either broccoli or broccoli sprouts), or extracts of broccoli seeds or sprouts-glucoraphanin-rich, sulforaphane-rich, or both. These studies are, of course, not all straightforward, and measurement of the broccoli-derived ingredients can be a source of mystery, obfuscation, and confusion, that is readily exploited by the supplement industry. Nonetheless, many clinical studies have now been done, and some overarching learnings can begin to be formulated. We and others have spent much time assessing bioavailability, conversion of glucoraphanin to sulforaphane, safety, and the classic ADME (absorption, distribution, metabolism, and excretion) pharmacokinetic parameters discussed in a previous section of this review. Efficacy has been studied much less thoroughly, but a picture is beginning to emerge. The following areas (in alphabetical order) have received special attention:

\subsubsection{Aflatoxin Toxicity}

The levels of aflatoxins from stored, subsistence seeds (corn and peanuts) in the Qidong area of coastal China near Shanghai, have in recent history been exceedingly high, as has associated incidence of liver cancer. Broccoli sprouts have been successfully piloted as a preventive intervention, and much data has been generated on safety and efficacy [biomarkers], as well as tolerance and acceptance by the local population [88,89];

\subsubsection{Air Pollution Detoxification}

The natural laboratory in Qidong further served to study the effects of broccoli spouts on detoxication of volatile organic air pollutants $[69,77,78,90]$. Others, in other environments, have examined effects of diesel exhaust (particulate) and other air pollutants [91,92];

\subsubsection{Arthritis}

Early work by Healy and collaborators suggested an effect on shear stress in chondrocytes [93]. This has now been followed by the elegant demonstration that increasing broccoli intake results in isothiocyanate (e.g., sulforaphane) uptake into the joint, with concomitant changes in the joint [59]. Much other work on anti-inflammatory properties of sulforaphane may ultimately be related to arthritis;

\subsubsection{Asthma and Atopic Allergic Responses}

A variety of relatively small but significant effects of sulforaphane have been demonstrated in a number of relatively complex experimental systems [73,92,94-97];

\subsubsection{Cancer Biomarkers}

A large variety of biomarkers have now been reported following sulforaphane treatment. The cancers being studied include: Breast [55,98], lung [99]; gastric [100], colo-rectal [101], prostate [79,80,102,103], skin [75,83,84,104], head and neck [72], and liver [90];

\subsubsection{COPD}

A 90-subject, three-center RCT was conducted with sulforaphane-rich broccoli sprout extract in which no effect was seen on patients with advanced COPD. Post-facto reasoning suggested that the already severely degraded condition of subjects' airways may well not have permitted for 
responsiveness (Nrf2-related and anti-inflammatory) regardless of the agent used [105]. A follow-up analysis suggests that there was compartmentalization of anti-oxidant and anti-inflammatory gene expression in current and former smokers with COPD [106];

\subsubsection{CVD}

At least three different groups have reported effects that included biochemical markers [107], blood pressure and flow-mediated dilation [108], and plasma metabolite biomarkers [82,85];

\subsubsection{Diabetes, Metabolic Syndrome, and Related Disorders}

Many clinical studies from at least three different groups have now been published. They have shown effects on reduced gluconeogenesis [86], inflammatory markers [109], and insulin resistance [110-112];

\subsubsection{General}

Extensive measures in a variety of studies have documented upregulation of key chemoprotective enzymes. To name only a few studies not mentioned elsewhere in this review: [113,114];

\subsubsection{Helicobacter Pylori Infection}

Our initial observations in vitro and in an animal model [11] have been translated to some eradication and more importantly, reduction of the levels of $H$. pylori colonization and gastric inflammation in some infected individuals [115-117];

\subsubsection{NASH/NAFLD}

Positive changes in liver function markers have been observed [118] and much interest continues, based upon encouraging pre-clinical studies;

\subsubsection{Neurodegenerative Conditions}

Small studies showing effects on GSH levels and mapping GSH elevations to specific brain regions have generated much excitement $[5,81]$;

\subsubsection{Neurodevelopmental Conditions}

One successful and highly visible study showing improvement of conditions of autism spectrum disorder (ASD) following consumption of sulforaphane from broccoli sprouts [87,119] is now being followed up with at least five studies with ASD subjects, two with schizophrenia, and one with psychoses. Results of only one of these follow-on studies has published so far [120];

\subsubsection{Sickle Cell Disease}

Although only a single, small, dose escalation Phase 1 trial has been run, a limited number of disease-relevant pharmacodynamic endpoints were queried, and safety was evaluated through a relatively high calculated dose [74].

\subsection{Summary of Clinical Studies with Sulforaphane, Glucoraphanin or Mixtures}

Table 1 summarizes the published literature of clinical trials conducted with broccoli-based preparations, sulforaphane and/or glucoraphanin. Also included are clinical trials listed on ClinicalTrials. gov that are known to be underway. Pending trials are not included. Oral doses that delivered sulforaphane directly ranged from 9.9 to $847 \mu \mathrm{mol}$ per person per day (median $100 \mu \mathrm{mol}$ ) and for glucoraphanin 25 to $800 \mu \mathrm{mol}$ per person per day (median $190 \mu \mathrm{mol}$ ). The trend towards the use of higher doses of glucoraphanin versus sulforaphane reflect considerations on the part of study directors on the limited conversion of glucoraphanin to sulforaphane in the absence of exogenous myrosinase in beverage or dietary supplement preparations. 
The harsh taste (a.k.a. back-of-the-throat burning sensation) that is noticed by most people who consume higher doses of sulforaphane, must be acknowledged and anticipated by investigators. They must make accommodations for what some subjects may consider a highly objectionable taste. This is particularly so at the higher limits of dosing with sulforaphane, and not so much of a concern when dosing with glucoraphanin, or even with glucoraphanin-plus-myrosinase. It is this harsh or burning sensation that has led in part to the characterization of the glucosinolate-myrosinase-isothiocyanate system as "the mustard oil bomb" [121]. This should not, however, be confused with the bitter descriptor leveled at most brassica vegetables and moringa, that appears to have more to do with the TAS2R class of taste receptors.

The presence and/or enzymatic production of levels of sulforaphane in oral doses ranging above about $100 \mu \mathrm{mol}$, creates a burning taste that most consumers notice in the back of their throats rather than on the tongue. This prevents some from consuming broccoli/sulforaphane preparations. Higher doses of sulforaphane lead to an increased number of adverse event reports, primarily nausea, heartburn, or other gastrointestinal discomfort $[44,67,87,119,122]$. We have conducted scientifically guided studies to mask or distract consumers from that very distinctive taste, and to facilitate the development of proper placebos [122,123]. 
Table 1. Summary of Clinical Trials with Broccoli, Glucoraphanin or Sulforaphane.

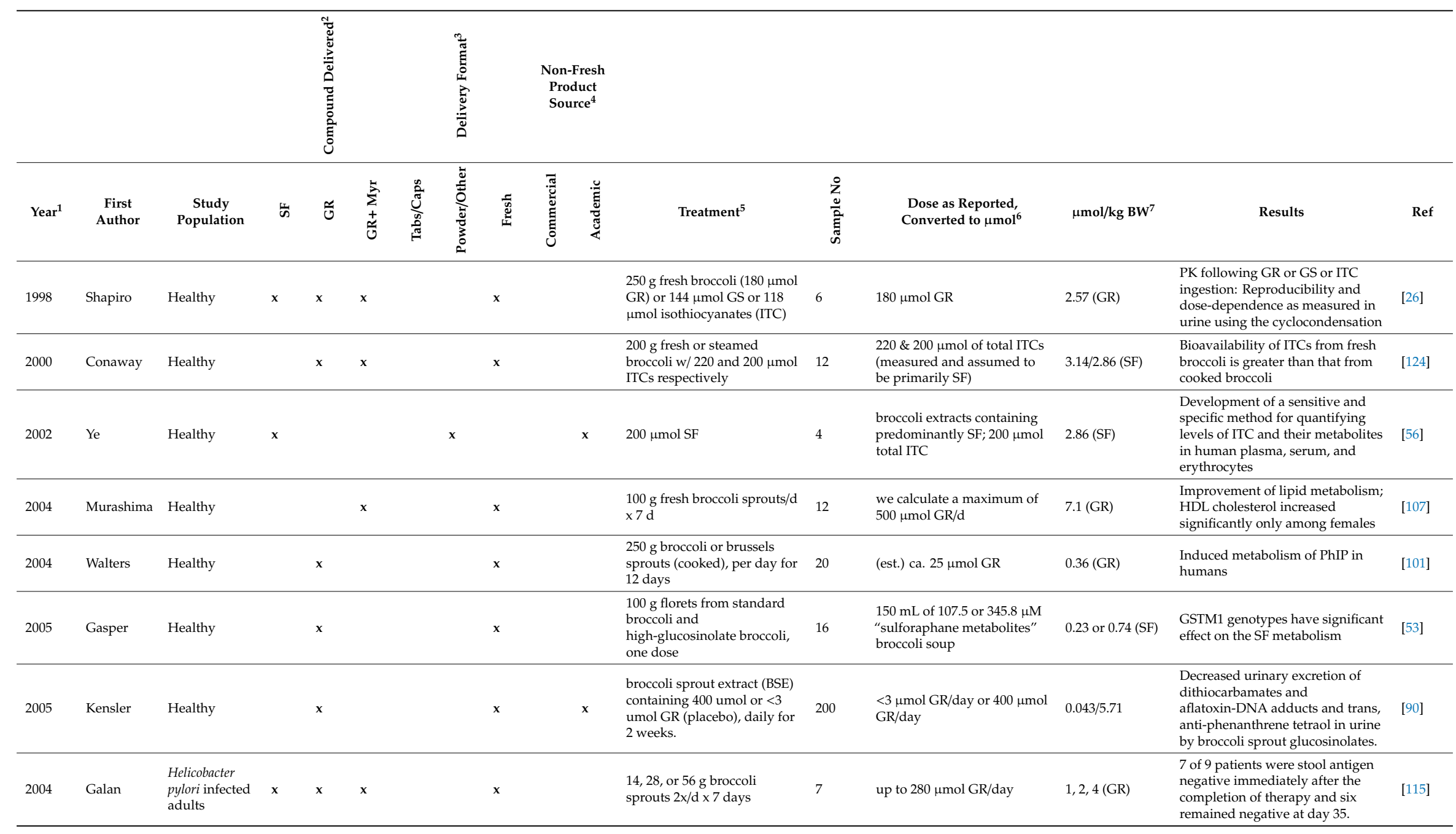


Table 1. Cont.

\begin{tabular}{|c|c|c|c|c|c|c|c|c|c|c|c|c|c|c|c|c|}
\hline & & & & 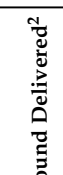 & & & 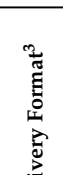 & & $\begin{array}{c}\text { Non- } \\
\text { Pro } \\
\text { Sou }\end{array}$ & $\begin{array}{l}\text { Fresh } \\
\text { duct } \\
\text { rce }\end{array}$ & & & & & & \\
\hline Year $^{1}$ & $\begin{array}{c}\text { First } \\
\text { Author }\end{array}$ & $\begin{array}{c}\text { Study } \\
\text { Population }\end{array}$ & 岕 & 은 & 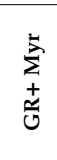 & 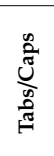 & 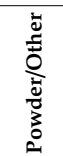 & 惡 & 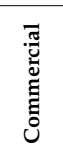 & 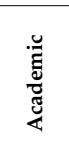 & Treatment $t^{5}$ & 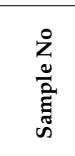 & $\begin{array}{l}\text { Dose as Reported, } \\
\text { Converted to } \mu \mathrm{mol}^{6}\end{array}$ & $\mu \mathrm{mol} / \mathrm{kg} \mathrm{BW}{ }^{7}$ & Results & Ref \\
\hline 2006 & Shapiro & Healthy & $\mathrm{x}$ & $\mathrm{x}$ & & & & & & $x$ & $\begin{array}{l}\text { BSE containing } 25 \mu \mathrm{mol} \text { GR, } \\
100 \mu \mathrm{mol} \text { GR, or } 25 \mu \mathrm{mol} \mathrm{SF}, \\
3 \times / \mathrm{d} \times 7 \mathrm{~d}\end{array}$ & 12 & $\begin{array}{l}75 \& 300 \mu \mathrm{mol} \mathrm{GR/d} ; 75 \mu \mathrm{mol} \\
\mathrm{SF} / \mathrm{d}\end{array}$ & $\begin{array}{l}1.97 \& 4.29(\mathrm{GR}) ; \\
1.07(\mathrm{SF})\end{array}$ & $\begin{array}{l}\text { Cumulative excretion of SF } \\
\text { metabolites similar regardless of } \\
\text { GR dose, \& much higher when } \\
\text { taking SF; diurnal cycling obser. }\end{array}$ & [61] \\
\hline 2007 & Cornblatt & $\begin{array}{l}\text { Reduction } \\
\text { mammaplasty }\end{array}$ & $x$ & & & & $x$ & & & & $\begin{array}{l}\text { SF-rich beverage (containing } \\
200 \mu \text { mole SF) }\end{array}$ & 8 & $200 \mu \mathrm{mol}$ SF once & 2.86 (SF) & $\begin{array}{l}\text { Measured serum and mammary } \\
\text { tissue levels of SF metabolites }\end{array}$ & [55] \\
\hline 2007 & Gasper & Healthy & $\mathrm{x}$ & & & & & $\mathrm{x}$ & & & $\begin{array}{l}\text { "standard" and "HG" } \\
\text { broccoli florets microwaved } \\
\text { gently to make soup }\end{array}$ & 16 & $\begin{array}{l}683 \text { and } 2296 \mu \mathrm{M} \mathrm{SF} \\
\text { measured }\end{array}$ & $1.42 / 4.92(\mathrm{SF})$ & $\begin{array}{l}\text { Consumption of high glucosinolate } \\
\text { broccoli resulted in up-regulation } \\
\text { of several xenobiotic metabolizing } \\
\text { genes in gastric mucosal tissue }\end{array}$ & [100] \\
\hline 2007 & Myzak & Healthy & & & $\mathrm{x}$ & & & $\mathrm{x}$ & & & $\begin{array}{l}68 \mathrm{~g} \text { broccoli sprouts } \\
\text { (approximately } 105 \mathrm{mg} \mathrm{SF} \text { ) }\end{array}$ & 3 & $\begin{array}{l}847 \mu \mathrm{mol} S \mathrm{SF} \text { if all converted } \\
\text { from GR using author's } \\
\text { estimate; } 136 \mu \mathrm{mol} \mathrm{SF} \text { using } \\
\text { our estimate }\end{array}$ & $\begin{array}{l}12.1 \text { (auth)/1.9 } \\
\text { (us) (SF) }\end{array}$ & $\begin{array}{l}\text { HDAC activity was significantly } \\
\text { inhibited in PBMC }\end{array}$ & [125] \\
\hline 2007 & Rungapame & strffealthy & $x$ & $\mathrm{x}$ & $\mathrm{x}$ & & $\mathrm{x}$ & $\mathrm{x}$ & & & $\begin{array}{l}150 \mathrm{~g} \text { lightly cooked broccoli } \\
\text { or fully cooked broccoli or a } \\
\text { broccoli seed extract with } \\
\text { added mustard seed }\end{array}$ & 12 & $\begin{array}{l}62 \& 71.7 \mu \mathrm{mol} \mathrm{GR} / \mathrm{d} \text { or } 2.7 \\
\mu \mathrm{mol} \mathrm{SF}\end{array}$ & $0.89 / 1.0$ (GR) & $\begin{array}{l}\text { Estimated yield of SF was } ~ 3 \text {-fold } \\
\text { higher after consumption of lightly } \\
\text { cooked brocoli than fully cooked } \\
\text { broccoli. Meal matrix did not } \\
\text { significantly influence the } \\
\text { hydrolysis of GR and its excretion } \\
\text { as SF }\end{array}$ & [126] \\
\hline 2008 & Traka & $\begin{array}{l}\text { Diagnosed } \\
\text { with } \\
\text { high-grade } \\
\text { prostatic } \\
\text { intraepithelial } \\
\text { neoplasia } \\
\text { (PIN) }\end{array}$ & & $\mathrm{x}$ & & & & $\mathrm{x}$ & & & $150 \mathrm{~g}$ broccoli $/ \mathrm{d}$ & 22 & $79.3 \mu \mathrm{mol} \mathrm{GR} / \mathrm{d}$ & 1.13 (GR) & $\begin{array}{l}\text { Showed complex change in } \\
\text { signaling pathways associated } \\
\text { with inflammation and } \\
\text { carcinogenesis: Modified by } \\
\text { GSTM1 genotype in broccoli } \\
\text { feeding group }\end{array}$ & [79] \\
\hline 2008 & Vermeulen & Healthy & $\mathrm{x}$ & $\mathrm{x}$ & & & & $\mathrm{x}$ & & & $\begin{array}{l}200 \mathrm{~g} \text { crushed raw or cooked } \\
\text { broccoli }\end{array}$ & 8 & $\begin{array}{l}9.92 \mu \mathrm{mol} \mathrm{SF} \text { or } 61.4 \mu \mathrm{mol} \\
\text { GR/d }\end{array}$ & $\begin{array}{l}0.14(\mathrm{SF}) / 0.88 \\
(\mathrm{GR})\end{array}$ & $\begin{array}{l}\text { 10x greater bioavailability of SF w/ } \\
\text { crushed, raw vs. microwaved } \\
\text { broccoli }\end{array}$ & [127] \\
\hline 2009 & Hanlon & Healthy & $\mathrm{x}$ & & & & & $\mathrm{x}$ & & & $\begin{array}{l}300 \mathrm{~mL} \text { of homogenized raw } \\
\text { broccoli } \mathrm{w} / 3.9 \mathrm{mg} \mathrm{SF} \text {, for } 10 \\
\text { consecutive days }\end{array}$ & 6 & $22 \mu \mathrm{mol} \mathrm{SF} / \mathrm{d}$ & 0.31 (SF) & $\begin{array}{l}\text { Repeated intake of broccoli had no } \\
\text { impact on the pharmacokinetic } \\
\text { behavior or plasma levels of SF }\end{array}$ & [128] \\
\hline
\end{tabular}


Table 1. Cont.

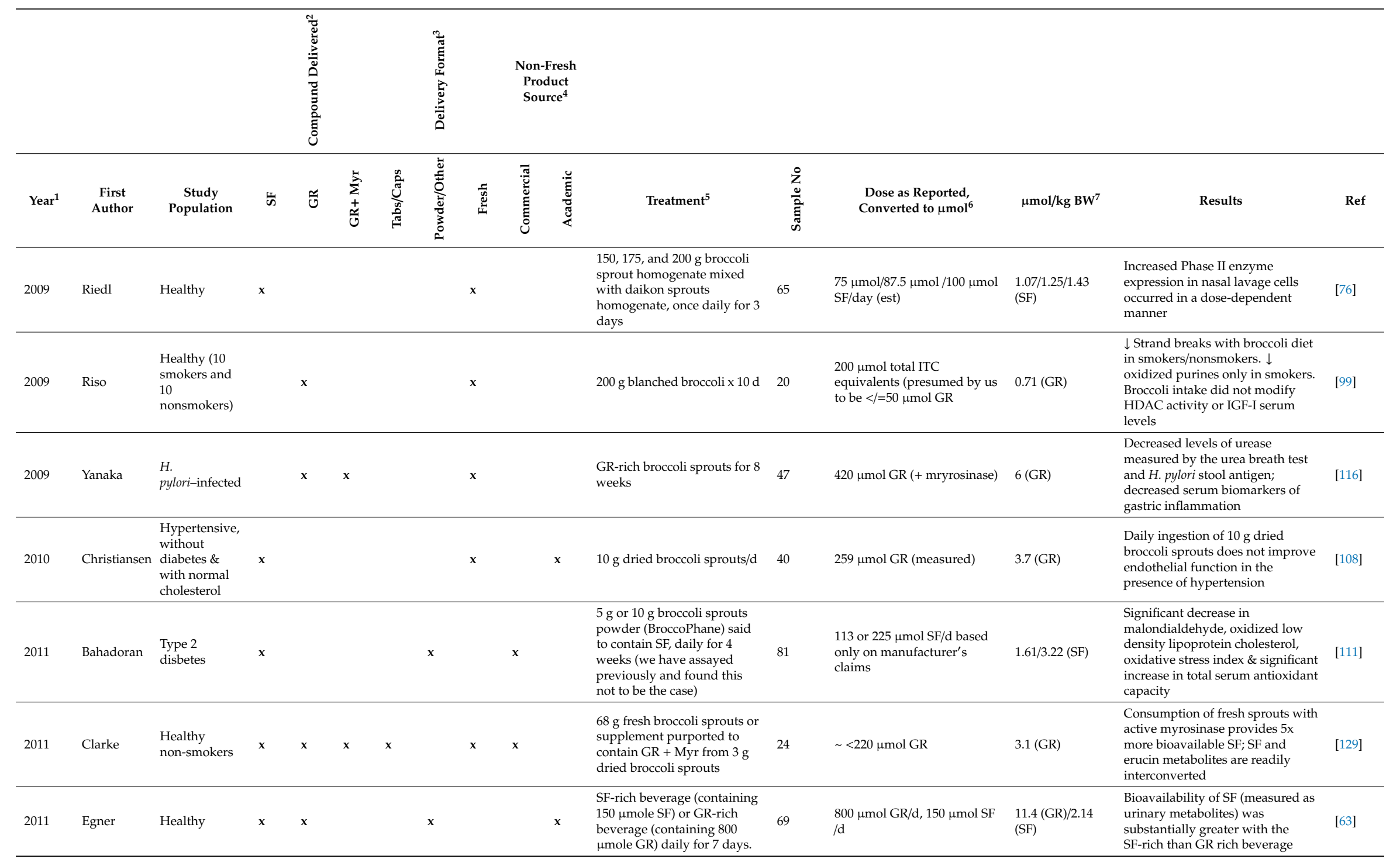


Table 1. Cont.

\begin{tabular}{|c|c|c|c|c|c|c|c|c|c|c|c|c|c|c|c|c|}
\hline & & & & 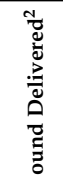 & & & 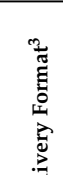 & & $\begin{array}{l}\text { Non- } \\
\text { Pro } \\
\text { Sor }\end{array}$ & $\begin{array}{l}\text { Fresh } \\
\text { duct } \\
\text { irce }\end{array}$ & & & & & & \\
\hline Year $^{1}$ & $\begin{array}{c}\text { First } \\
\text { Author }\end{array}$ & $\begin{array}{c}\text { Study } \\
\text { Population }\end{array}$ & 岕 & ษ̃ & 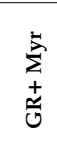 & 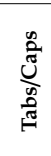 & 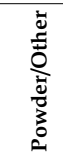 & 离 & 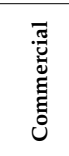 & 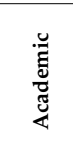 & Treatment $t^{5}$ & $\begin{array}{l}\frac{2}{z} \\
\frac{0}{2} \\
\text { हू } \\
\text { के }\end{array}$ & $\begin{array}{l}\text { Dose as Reported, } \\
\text { Converted to } \mu \mathrm{mol}^{6}\end{array}$ & $\mu \mathrm{mol} / \mathrm{kg} \mathrm{BW}^{7}$ & Results & $\operatorname{Re}$ \\
\hline 2011 & Healy & Healthy & & $\mathrm{x}$ & & & $x$ & & & $x$ & $\begin{array}{l}561 \mathrm{mg} \text { BSE powder (200 } \\
\mu \mathrm{mol} \text { GR) }\end{array}$ & 4 & $200 \mu \mathrm{mol}$ GR/d & $2.86(\mathrm{GR})$ & $\begin{array}{l}\text { Consumption of BSE showed } \\
\text { inactivation of urinary MIF } \\
\text { tautomerase activity in urine }\end{array}$ & [113] \\
\hline 2011 & Hauder & $\begin{array}{l}\text { Healthy male } \\
\text { non-smoking } \\
\text { (50-82 y.o.) }\end{array}$ & & $\mathrm{x}$ & & & & $x$ & & & $\begin{array}{l}200 \mathrm{~g} \text { of blanched, regular or } \\
\text { selenium-fertilized broccoli, } \\
\text { daily, for } 4 \text { weeks }\end{array}$ & 76 & $\begin{array}{l}\text { broccoli contained either } 133 \\
\text { or } 226 \mu \mathrm{g} / \mathrm{g} \text { of GR }\end{array}$ & 0.87 or $1.48(\mathrm{GR})$ & $\begin{array}{l}\text { Dietary intake of } \\
\text { seleniumm-fertilized broccoli } \\
\text { increased serum selenium } \\
\text { concentration, but affected neither } \\
\text { glucosinolate concentrations in } \\
\text { broccoli nor their metabolite levels } \\
\text { in plasma and urine compared to } \\
\text { regular broccoli. }\end{array}$ & [130] \\
\hline 2012 & Bahadoran & $\begin{array}{l}\text { Type } 2 \\
\text { diabetes }\end{array}$ & $\mathrm{x}$ & & & & $\mathrm{x}$ & & $x$ & & $\begin{array}{l}10 \mathrm{~g} \text { or } 5 \mathrm{~g} \text { broccoli sprouts } \\
\text { powder (BroccoPhane) said } \\
\text { to contain } \mathrm{SF} \text {, daily for } 4 \\
\text { weeks. }\end{array}$ & 81 & $\begin{array}{l}113 \text { or } 225 \mu \mathrm{mol} \text { SF/day based } \\
\text { only on manufacturer's } \\
\text { claims }\end{array}$ & $1.61 / 3.22(\mathrm{SF})$ & $\begin{array}{l}\text { Consumption of } 10 \mathrm{~g} / \mathrm{d} \text { resulted in } \\
\text { a significant decrease in serum } \\
\text { insulin concentration and } \\
\text { HOMA-IR }\end{array}$ & [112] \\
\hline 2012 & Cramer & Healthy & & $\mathrm{x}$ & $\mathrm{x}$ & & & $\mathrm{x}$ & $\mathrm{x}$ & & $\begin{array}{l}2 \mathrm{~g} \text { GR powder or } 42 \mathrm{~g} \text { fresh } \\
\text { broccoli sprouts/d; once a } \\
\text { week for } 4 \text { weeks }\end{array}$ & 4 & $\begin{array}{l}120 \mu \mathrm{mol} \text { GR/d or } 70 \mu \mathrm{mol} \\
\text { GR (fresh sprouts with active } \\
\text { myrosinase)/d }\end{array}$ & $1.71 / 1$ (GR) & $\begin{array}{l}\text { Adding fresh broccoli sprouts (as a } \\
\text { source of myrosinase) to GR } \\
\text { synergistically enhanced } \\
\text { absorption and excretion }\end{array}$ & [131] \\
\hline 2012 & Fahey & Healthy & & $\mathrm{x}$ & & & $x$ & & & $x$ & $200 \mu \mathrm{mol}$ GR & 131 & $200 \mu \mathrm{mol} \mathrm{GR}$ & $2.86(\mathrm{GR})$ & $\begin{array}{l}\text { Extreme inter-individual range of } \\
\text { conversion efficiencies (1-40\% of } \\
\text { administered dose of GR) } \\
\text { attributed to differences in } \\
\text { microbiomes as well as circadian } \\
\text { rythm; within-individual } \\
\text { differences were less pronounced }\end{array}$ & [65] \\
\hline 2012 & Kensler & Healthy & $x$ & $x$ & & & $\mathrm{x}$ & & & $x$ & $\begin{array}{l}\text { Cross-over design: GR-rich } \\
\text { beverage }(800 \text { umol GR) } \rightarrow \\
\text { SF-rich beverage }(150 \mu \mathrm{mol} \\
\text { SF)/SF-rich beverage }(150 \\
\mu \mathrm{mol} \text { SF) } \rightarrow \text { GR-rich beverage } \\
(800 \mu \mathrm{mol} \text { GR })\end{array}$ & 50 & $\begin{array}{l}800 \mu \mathrm{mol} \text { GR/day, } 150 \mu \mathrm{mol} \\
\mathrm{SF} / \mathrm{d}\end{array}$ & $\begin{array}{l}11.4(\mathrm{GR}) / 2.14 \\
(\mathrm{SF})\end{array}$ & $\begin{array}{l}\text { Statistically significant increases in } \\
\text { the levels of excretion of } \\
\text { glutathione-derived conjugates of } \\
\text { benzene and acrolein, but not } \\
\text { crotonaldehyde in groups } \\
\text { receiving SF-rich, GR-rich } \\
\text { beverages or both compared to } \\
\text { preintervention values }\end{array}$ & [77] \\
\hline
\end{tabular}


Table 1. Cont.

\begin{tabular}{|c|c|c|c|c|c|c|c|c|c|c|c|c|c|c|c|c|}
\hline & & & & 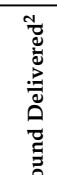 & & & 苞 & & $\begin{array}{l}\text { Non- } \\
\text { Pro } \\
\text { Sor }\end{array}$ & $\begin{array}{l}\text { Fresh } \\
\text { duct } \\
\text { Irce }\end{array}$ & & & & & & \\
\hline Year $^{1}$ & $\begin{array}{c}\text { First } \\
\text { Author }\end{array}$ & $\begin{array}{c}\text { Study } \\
\text { Population }\end{array}$ & 岕 & 우 & 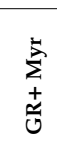 & 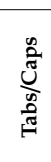 & 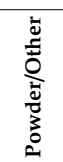 & 趸 & 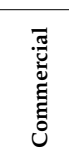 & 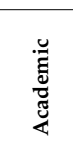 & Treatment $t^{5}$ & 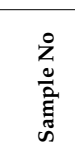 & $\begin{array}{l}\text { Dose as Reported, } \\
\text { Converted to } \mu \mathrm{mol}^{6}\end{array}$ & $\mu \mathrm{mol} / \mathrm{kg} \mathrm{BW}^{7}$ & Results & Ref \\
\hline 2012 & Mirmiran & $\begin{array}{l}\text { Type } 2 \\
\text { diabetes }\end{array}$ & $\mathrm{x}$ & & $\mathrm{x}$ & & $\mathrm{x}$ & & $\mathrm{x}$ & & $\begin{array}{l}5 \text { or } 10 \mathrm{~g} / \mathrm{d} \text { of BroccoPhane } \\
\text { powder (BSP), reported to be } \\
\text { rich in SF, - daily } 4 \text { wks (we } \\
\text { have assayed previously and } \\
\text { found this not to be the case) }\end{array}$ & 81 & $\begin{array}{l}113 \text { or } 225 \mu \mathrm{mol} \mathrm{SF} / \text { day based } \\
\text { only on manufacturer's } \\
\text { claims }\end{array}$ & $1.61 / 3.22(\mathrm{SF})$ & $\begin{array}{l}\text { Sera of BSP treatment groups } \\
\text { showed } \downarrow \text { hs-CRP, and } \\
\text { non-significant } \downarrow \text { IL-6 and TNF- } \alpha\end{array}$ & [110] \\
\hline 2012 & Saha & Healthy & $\mathrm{x}$ & $\mathrm{x}$ & & & & $\mathrm{x}$ & & & $\begin{array}{l}\text { Broccoli soups produced } \\
\text { from fresh or frozen broccoli } \\
\text { florets }\end{array}$ & 18 & $\begin{array}{l}4.16 \mathrm{mg} \mathrm{SF} / \mathrm{serv}(23.5 \mu \mathrm{mol}) \\
\text { or } 18.6 \mathrm{mg} \mathrm{GR} / \mathrm{serv} .(42.7 \\
\mu \mathrm{mol})\end{array}$ & $\begin{array}{l}0.33(\mathrm{SF}) / 0.61 \\
(\mathrm{GR})\end{array}$ & $\begin{array}{l}\text { SF bioavailability was } 10 x \text { higher } \\
\text { in fresh compared to frozen } \\
\text { broccoli }\end{array}$ & [132] \\
\hline 2013 & Armah & $\begin{array}{l}\text { 10-y CVD risk } \\
\text { profile }\end{array}$ & & $\mathrm{x}$ & & & & $\mathrm{x}$ & & & $\begin{array}{l}400 \mathrm{~g} \text { standard or "HG" } \\
\text { broccoli or placebo vegetable } \\
\text { (peas) for } 12 \text { wk }\end{array}$ & 54 & $\begin{array}{l}6.9 \text { or } 21.6 \mu \mathrm{mol} \mathrm{GR} / \mathrm{g} \text { dry wt } \\
\text { broccoli }\end{array}$ & 1.48/4.63 (GR) & $\begin{array}{l}\text { No significant differences on } \\
\text { markers of CVD risk }\end{array}$ & [82] \\
\hline 2013 & Meyer & Healthy & $\mathrm{x}$ & & & & & $\mathrm{x}$ & & & $\begin{array}{l}\text { SF-rich homogenate prepared } \\
\text { from } 200 \mathrm{~g} \text { BroccoSprouts } \\
\text { (assayed for SF) daily for } 3 \\
\text { consecutive days }\end{array}$ & 12 & $100 \mu \mathrm{mol}$ SF/day (our est.) & $1.43(\mathrm{SF})$ & $\begin{array}{l}\text { Homogenate significantly } \\
\text { increased secretory leukocyte } \\
\text { protease inhibitor levels in nasal } \\
\text { lavage fluid }\end{array}$ & [94] \\
\hline 2013 & Poulton & Healthy & $\mathrm{x}$ & & & & $\mathrm{x}$ & & & & $\begin{array}{l}\text { BSE }(450 \mu \mathrm{mol} \mathrm{SF} / \mathrm{d} \times 7 \mathrm{~d} \\
\text { delivered in cheese-based } \\
\text { soup }\end{array}$ & 23 & $450 \mu \mathrm{mol} \mathrm{SF} / \mathrm{d}$ & $6.43(\mathrm{SF})$ & No effect on CYP3A4 activity & [44] \\
\hline 2014 & Bahadoran & $\begin{array}{l}\text { Type 2 } \\
\text { diabetic with } \\
\text { H. pylori } \\
\text { infection }\end{array}$ & $\mathrm{x}$ & & & & $\mathrm{x}$ & & $\mathrm{x}$ & & $\begin{array}{l}6 \mathrm{~g} / \mathrm{d} \text { of Cyvex broccoli } \\
\text { sprouts powder (BSP), } \\
\text { reported to be rich in SF, (we } \\
\text { have assayed previously and } \\
\text { found this not to be the case), } \\
\text { daily, in combination with } \\
\text { other drugs, for up to } 28 \mathrm{~d}\end{array}$ & 86 & $\begin{array}{l}\text { Maximum possible is } 135 \\
\mu \text { mol SF/day }\end{array}$ & $1.93(\mathrm{SF})$ & $\begin{array}{l}\text { BSP } \downarrow \text { H. pylori load in diabetic } \\
\text { patients, but no effect on gastric } \\
\text { inflammatory markers }\end{array}$ & [117] \\
\hline 2014 & Baier & Healthy & & & $\mathrm{x}$ & & & $\mathrm{x}$ & & & $\begin{array}{l}34,68 \text { or } 102 \mathrm{~g} \text { Broccoli } \\
\text { sprouts }\end{array}$ & 8 & $\begin{array}{l}\text { 170, } 340 \text {, and } 680 \mu \mathrm{mol} \\
\text { GR/day }\end{array}$ & 2.4/4.8/9.6 (GR) & $\begin{array}{l}\text { Dose dependent elevation in LTR } \\
\text { (long terminal repeats) mRNA \& } \\
\text { histone acetylation in circulating } \\
\text { leukocytes }\end{array}$ & [133] \\
\hline 2014 & Egner & Healthy & $\mathrm{x}$ & $\mathrm{x}$ & & & $\mathrm{x}$ & & & $\mathrm{x}$ & $\begin{array}{l}\text { broccoli sprouts beverages } \\
\text { containing GR-rich and } \\
\text { SF-rich powders }(600 \mu \text { mol } \\
\text { GR }+40 \mu \text { mol SF), daily, for } \\
150 \text { days }\end{array}$ & 267 & $\begin{array}{l}600 \text { umol GR/day + } 40 \mu \mathrm{mol} \\
\text { SF/day }\end{array}$ & $\begin{array}{l}8.57(\mathrm{GR})+0.57 \\
(\mathrm{SF})\end{array}$ & $\begin{array}{l}\text { Significant increases in the levels } \\
\text { of excretion of the } \\
\text { glutathione-derived conjugates of } \\
\text { benzene and acrolein in urine in } \\
\text { broccoli sprout beverage treatment } \\
\text { group }\end{array}$ & [78] \\
\hline
\end{tabular}


Table 1. Cont.

\begin{tabular}{|c|c|c|c|c|c|c|c|c|c|c|c|c|c|c|c|c|}
\hline & & & & 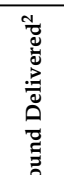 & & & 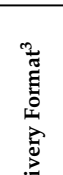 & & $\begin{array}{c}\text { Non- } \\
\text { Pro } \\
\text { Sou }\end{array}$ & $\begin{array}{l}\text { resh } \\
\text { uct } \\
\text { ce }^{4}\end{array}$ & & & & & & \\
\hline Year $^{1}$ & $\begin{array}{l}\text { First } \\
\text { Author }\end{array}$ & $\begin{array}{c}\text { Study } \\
\text { Population }\end{array}$ & 岕 & ธิ & 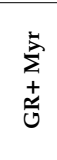 & 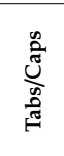 & 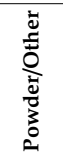 & 矛 & 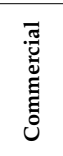 & 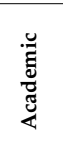 & Treatment $^{5}$ & 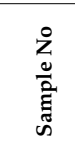 & $\begin{array}{l}\text { Dose as Reported, } \\
{\text { Converted to } \mu \mathrm{mol}^{6}}^{6}\end{array}$ & $\mu \mathrm{mol} / \mathrm{kg} \mathrm{BW}{ }^{7}$ & Results & Ref \\
\hline 2014 & Heber & Healthy & $\mathrm{x}$ & & & & $\mathrm{x}$ & & & $\mathrm{x}$ & $\begin{array}{l}1.25 \mathrm{~g} \text { BSE suspended in juice } \\
(100 \mu \mathrm{mol} S \mathrm{SF} / \mathrm{d} \times 4 \mathrm{~d})\end{array}$ & 29 & $100 \mu \mathrm{mol} \mathrm{SF} / \mathrm{d}$ & $1.43(\mathrm{SF})$ & $\begin{array}{l}\text { Subjects challenged } \mathrm{w} / \text { repeated } \\
\text { nasal diesel exhaust particles: } \\
\text { WBC decreased } 54 \% \text { by daily BSE }\end{array}$ & [91] \\
\hline 2014 & Noah & Healthy & $\mathrm{x}$ & & & & & $\mathrm{x}$ & & & $\begin{array}{l}\text { smokers/nonsmokers - } \\
\text { broccoli sprout homogenate }\end{array}$ & $16 / 35$ & $100 \mu \mathrm{mol}$ SF/d (est) & $1.43(\mathrm{SF})$ & $\begin{array}{l}\text { Post BSH, live attenuated influenza } \\
\text { virus-induced inflammatory } \\
\text { markers reduced; NQO1 increased, } \\
\text { in smokers but not non-smokers }\end{array}$ & [92] \\
\hline 2014 & Singh & $\begin{array}{l}0^{\Upsilon}, 13-27 \text { y.o. } \\
\text { with moderate } \\
\text { to severe } \\
\text { Autism } \\
\text { Spectrum } \\
\text { Disorder }\end{array}$ & $\mathrm{x}$ & & & $\mathrm{x}$ & & & & $\mathrm{x}$ & $\begin{array}{l}50-150 \mu \mathrm{mol} \mathrm{SF/d} \mathrm{x} 18 \\
\text { weeks; dosed by BW }\end{array}$ & 44 & $50 \mu \mathrm{mol} \mathrm{SF} / \mathrm{d}-150 \mu \mathrm{mol} \mathrm{SF} / \mathrm{d}$ & $0.71-2.14$ (SF) & $\begin{array}{l}\text { SF showed substantial declines } \\
\text { (improvement of behavior) in } \\
\text { Aberrant Behavior Checklist and } \\
\text { Social Responsiveness Scale scores }\end{array}$ & [87] \\
\hline 2015 & Alumkal & $\begin{array}{l}\text { Prostate } \\
\text { cancer }\end{array}$ & $\mathrm{x}$ & & & $\mathrm{x}$ & & & & $\mathrm{x}$ & $\begin{array}{l}\text { SF-rich broccoli sprout } \\
\text { extract; } 200 \mu \mathrm{mol} / \mathrm{d} \text { x } 20 \\
\text { weeks }\end{array}$ & 20 & $200 \mu \mathrm{mol} \mathrm{SF} / \mathrm{d}$ & $2.86(\mathrm{SF})$ & Did not lead to $\geq 50 \%$ PSA declines & [103] \\
\hline 2015 & Armah & $\begin{array}{l}10 \text { Year } \\
\text { cardiovascular } \\
\text { risk profile of } \\
\text { between } 10 \\
\text { and } 20 \% \\
\end{array}$ & & $\mathrm{x}$ & & & & $\mathrm{x}$ & & & $\begin{array}{l}400 \mathrm{~g} \text { standard or " } \mathrm{HG}^{\prime \prime} \\
\text { broccoli or placebo vegetable } \\
\text { (peas) for } 12 \mathrm{wk}\end{array}$ & 130 & $\begin{array}{l}6.9 \text { or } 21.6 \mu \mathrm{mol} \mathrm{GR} / \mathrm{g} \text { dry wt } \\
\text { broccoli }\end{array}$ & $1.48 / 4.63$ (GR) & $\begin{array}{l}\text { High glucoraphanin (HG) broccoli } \\
\text { diet } \downarrow \text { plasma LDL-C more than } \\
\text { standard broccoli }\end{array}$ & [85] \\
\hline 2015 & Atwell & $\begin{array}{l}\text { Abnormal } \\
\text { mammograms; } \\
\text { scheduled for } \\
\text { breast biopsy }\end{array}$ & & & $\mathrm{x}$ & & $\mathrm{x}$ & & $\mathrm{x}$ & & $\begin{array}{l}\text { broccoli seed extract } \\
\text { containing GR (Brocomax); } \\
\text { [we have assayed previously } \\
\text { and found the myrosinase to } \\
\text { be inactive and the GR titer } \\
\text { to not be as represented], } 2 \\
\text { capsules, } 3 \times / \mathrm{d}, \mathrm{x} 2-8 \mathrm{wk}\end{array}$ & 54 & $\begin{array}{l}180 \mathrm{mg} \text { GR/day }(=413 \mu \mathrm{mol} \\
\mathrm{GR} / \mathrm{d})\end{array}$ & 5.9 (GR) & $\begin{array}{l}\downarrow \text { PBMC HDAC activity; } \\
\text { pre-to-post changes in Ki-67 and } \\
\text { HDAC3; NSD in tissue biomarkers } \\
\text { between placebo and treatment } \\
\text { group }\end{array}$ & [98] \\
\hline 2015 & Atwell & Healthy & $\mathrm{x}$ & $\mathrm{x}$ & & $\mathrm{x}$ & & $\mathrm{x}$ & & $\mathrm{x}$ & $\begin{array}{l}\text { fresh broccoli sprouts } \\
\text { (containing } 200 \mu \text { mol GR) or } \\
\text { SF-rich BSE (containing 200 } \\
\text { mol SF) daily, consumed } \\
\text { every } 12 \mathrm{~h} \text {. }\end{array}$ & 20 & $\begin{array}{l}200 \mu \mathrm{mol} \mathrm{SF} / \mathrm{d} ; 200 \mu \mathrm{mol} \\
\mathrm{GR} / \mathrm{d}\end{array}$ & $\begin{array}{l}3.33(\mathrm{SF}) ; 3.33 \\
(\mathrm{GR})\end{array}$ & $\begin{array}{l}3 \times \text { higher SF metabolite levels in } \\
\text { plasma and urine in sprout } \\
\text { consumers compared to SF-rich } \\
\text { BSE consumers }\end{array}$ & [57] \\
\hline
\end{tabular}


Table 1. Cont.

\begin{tabular}{|c|c|c|c|c|c|c|c|c|c|c|c|c|c|c|c|c|}
\hline & & & & 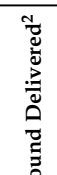 & & & 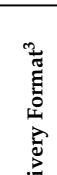 & & & $\begin{array}{l}\text { Fresh } \\
\text { duct } \\
\text { Irce }\end{array}$ & & & & & & \\
\hline Year $^{1}$ & $\begin{array}{l}\text { First } \\
\text { Author }\end{array}$ & $\begin{array}{c}\text { Study } \\
\text { Population }\end{array}$ & 岕 & $\approx$ & 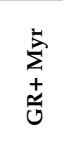 & 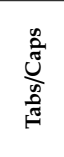 & 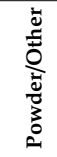 & 离 & 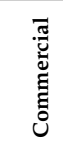 & 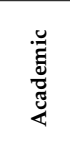 & Treatment $^{5}$ & 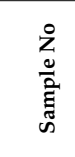 & $\begin{array}{l}\text { Dose as Reported, } \\
\text { Converted to } \mu \mathrm{mol}^{6}\end{array}$ & $\mu \mathrm{mol} / \mathrm{kg} \mathrm{BW}^{7}$ & Results & $\operatorname{Ref}$ \\
\hline 2015 & Brown & $\begin{array}{l}\text { Moderate } \\
\text { asthma }\end{array}$ & $x$ & & & $x$ & & & & $x$ & $\begin{array}{l}440 \mathrm{mg} \text { SF-rich BSE (100 } \\
\mu \mathrm{mol} \text { SF/d x } 14 \mathrm{~d} \text { ) }\end{array}$ & 45 & $100 \mu \mathrm{mol} \mathrm{SF} / \mathrm{d}$ & $1.43(\mathrm{SF})$ & $\begin{array}{l}\text { Individuals in whom SF treatment } \\
\text { enhanced the forced expiratory } \\
\text { volume response to methacholine, } \\
\text { had increased expression of } \\
\text { Nrf2-regulated antioxidant and } \\
\text { anti-inflammatory genes in } \\
\text { peripheral blood mononuclear } \\
\text { cells: SF treatment resulted in } \\
\text { significant reduction in airway } \\
\text { resistance and increased small } \\
\text { airway luminal area }\end{array}$ & [73] \\
\hline 2015 & Chang & H. pylori & $x$ & & & $x$ & & & $x$ & & $\begin{array}{l}\text { SF capsule twice daily for } 4 \\
\text { weeks. }\end{array}$ & 67 & $\begin{array}{l}2 \mathrm{mg} \mathrm{SF} / \mathrm{day}(11.3 \mu \mathrm{mol} \mathrm{SF} / \mathrm{d}) \\
\text { [we do not trust this } \\
\text { company's representation of } \\
\text { dose] }\end{array}$ & $0.16(\mathrm{SF})$ & $\begin{array}{l}\text { No significant difference in urea } \\
\text { breath test values or ammonia } \\
\text { concentration; SF did } \downarrow \text { gastric } \\
\text { mucosal malondialdehyde but not } \\
\text { glutathione levels }\end{array}$ & [134] \\
\hline 2015 & Cipolla & $\begin{array}{l}\text { Prostate } \\
\text { cancer } \\
\text { patients post- } \\
\text { radical } \\
\text { prostatectomy }\end{array}$ & $x$ & & & $x$ & & & $x$ & & $\begin{array}{l}\text { SF tablets ( } 2 \text { tablets } \\
\text { containing } 10 \mathrm{mg} \text { stabilized } \\
\text { SF extracted from broccoli } \\
\text { seeds, } 3 \text { times a day) for } 6 \\
\text { months }\end{array}$ & 78 & $\begin{array}{l}60 \mathrm{mg} \mathrm{SF} / \text { day }(339 \mu \mathrm{mol} \\
\mathrm{SF} / \mathrm{d})\end{array}$ & $4.83(\mathrm{SF})$ & $\begin{array}{l}\text { Decreased prostate-specific } \\
\text { antigen (PSA) levels }\end{array}$ & [102] \\
\hline 2015 & Fahey & Healthy & & $\mathrm{x}$ & $\mathrm{x}$ & $x$ & $\mathrm{x}$ & & $\mathrm{x}$ & $\mathrm{x}$ & $\begin{array}{l}50,69,100,200,230 \mu \mathrm{mol} G R \\
\text { in various dose forms } \\
\text { including comparing } \\
\text { commercial tablets to } \\
\text { investigator-prepared } \\
\text { materials and GR with active } \\
\text { myrosinase }\end{array}$ & 20 & $\begin{array}{l}50,69,100,200 \& 230 \mu \mathrm{mol} \\
\text { GR }\end{array}$ & $\begin{array}{l}0.7 / 1.0 / 1.4 / 2.9 / 3.3 \\
\text { (GR) }\end{array}$ & $\begin{array}{l}\text { Inter- and intra-individual } \\
\text { variabilities, when GR delivered in } \\
\text { teas, juices, or gelatin capsules; } \\
\text { established effect of adding active } \\
\text { myrosinase to the "dose" }\end{array}$ & [68] \\
\hline 2015 & Kikuchi & $\begin{array}{l}\text { Diagnosis of } \\
\text { fatty liver } \\
\text { with elevated } \\
\text { liver function } \\
\text { markers }\end{array}$ & & $\mathrm{x}$ & & & & & & & $\begin{array}{l}3 \text { broccoli sprout capsules } \\
\text { (containing } 30 \mathrm{mg} \mathrm{GR} \text { ) for } 2 \\
\text { months }\end{array}$ & 55 & $69 \mu \mathrm{mol} \mathrm{GR} / \mathrm{d}$ & 1 (GR) & $\downarrow$ serum ALT, AST, $\gamma$-GTP & [118] \\
\hline 2015 & Medina & Healthy & & & $\mathrm{x}$ & & & $\mathrm{x}$ & & & $\begin{array}{l}30 \mathrm{~g} \text { or } 60 \mathrm{~g} \text { of broccoli } \\
\text { sprouts }\end{array}$ & 24 & $\begin{array}{l}\sim 117 \text { or } 234 \mu \mathrm{mol} \mathrm{GR} \\
\text { (measured)/d as well as } \\
\text { much smaller amounts of SF } \\
\text { (measured) }\end{array}$ & $1.67 / 3.34$ (GR) & $\begin{array}{l}\text { Broccoli sprouts modulated } \\
\text { excretion of biomarkers linked to } \\
\text { inflammation and vascular } \\
\text { reactions without exerting a } \\
\text { significant influence on the } \\
\text { oxidation of phospholipids }\end{array}$ & [135] \\
\hline
\end{tabular}


Table 1. Cont.

\begin{tabular}{|c|c|c|c|c|c|c|c|c|c|c|c|c|c|c|c|c|}
\hline & & & & 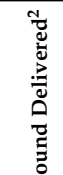 & & & 苞 & & $\begin{array}{l}\text { Non- } \\
\text { Pro } \\
\text { Sou }\end{array}$ & $\begin{array}{l}\text { Fresh } \\
\text { duct } \\
\text { Irce }\end{array}$ & & & & & & \\
\hline Year $^{1}$ & $\begin{array}{c}\text { First } \\
\text { Author }\end{array}$ & $\begin{array}{c}\text { Study } \\
\text { Population }\end{array}$ & 岕 & 은 & \begin{tabular}{l}
$\sum^{5}$ \\
+ \\
\multirow{2}{*}{}
\end{tabular} & 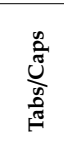 & 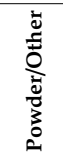 & 离 & 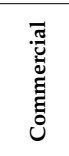 & $\frac{\breve{\Xi}}{\tilde{\Xi}}$ & Treatment $^{5}$ & 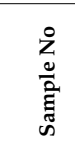 & $\begin{array}{l}\text { Dose as Reported, } \\
\text { Converted to } \mu \mathrm{mol}^{6}{ }^{6}\end{array}$ & $\mu \mathrm{mol} / \mathrm{kg} \mathrm{BW}^{7}$ & Results & Ref \\
\hline 2015 & Shiina & Schizophrenia & $\mathrm{x}$ & & & $\mathrm{x}$ & & & $\mathrm{x}$ & & $30 \mathrm{mg}$ GR $/ \mathrm{d} \times 8$ weeks & 10 & 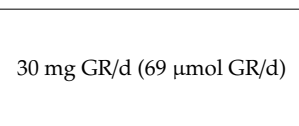 & 1 (GR) & $\begin{array}{l}\text { Mean score in the Accuracy } \\
\text { component of the One Card } \\
\text { Learning Task increased } \\
\text { significantly after the trial. }\end{array}$ & [136] \\
\hline 2015 & Ushida & Healthy & & $\mathrm{x}$ & & $\mathrm{x}$ & & & $\mathrm{x}$ & & $\begin{array}{l}\text { dried broccoli sprout } \\
\text { capsules ( } 3 \text { or } 6 \text { capsules rich } \\
\text { in GR) }\end{array}$ & 21 & 68.7 or $137.4 \mu \mathrm{mol}$ GR/day & $0.98 / 1.96(\mathrm{GR})$ & $\begin{array}{l}\text { Serum activities of GST and NQO1 } \\
\text { were dose-dependently and } \\
\text { synchronously elevated }\end{array}$ & [114] \\
\hline 2016 & Bauman & Healthy & & $\mathrm{x}$ & & & & & & $\mathrm{x}$ & 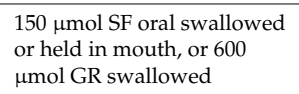 & 10 & & $\begin{array}{l}8.57(\mathrm{GR}) / 2.14 \\
(\mathrm{SF})\end{array}$ & $\begin{array}{l}\text { Clinical support for good mucosal } \\
\text { bioactivity and pharmacodynamic } \\
\text { activity }\end{array}$ & {$[72]$} \\
\hline 2016 & Doss & $\begin{array}{l}\text { Sickle cell } \\
\text { disease (SCD) }\end{array}$ & $\mathrm{x}$ & $\mathrm{x}$ & & & & $\mathrm{x}$ & & & $\begin{array}{l}\text { broccoli sprout homogenate } \\
\text { (BSH) made from 50, 100, or } \\
150 \mathrm{~g} \text { fresh BroccoSprouts }\end{array}$ & 16 & $\begin{array}{l}\text { 250, 500, or } 750 \mu \mathrm{mol} \mathrm{GR} \\
\text { [calculated maximum } \\
\text { delivery] }\end{array}$ & 3.6/7.1/10.7 (GR) & $\begin{array}{l}\text { Homogenate is safe in SCD } \\
\text { subjects; only modest changes in } \\
\text { NRF2-mediated gene expression }\end{array}$ & {$[74]$} \\
\hline 2016 & Duran & Healthy & & & $\mathrm{x}$ & & & $\mathbf{x}$ & & & $\begin{array}{l}\text { Homogenate prepared from } \\
111 \mathrm{~g} \text { BroccoSprouts once } \\
\text { daily for } 3 \text { days }\end{array}$ & 16 & $555 \mu \mathrm{mol}$ GR/day & 7.9 (GR) & $\begin{array}{l}\text { On last treatment day, subjects } \\
\text { were exposed to ozone with } \\
\text { intermittent moderate exercise to } \\
\text { induce airway inflammation: } \\
\text { Homogenate did not induce } \\
\text { expression of antioxidant genes in } \\
\text { blood and nasal epithelial cells }\end{array}$ & [97] \\
\hline 2016 & Müller & Healthy & & $\mathrm{x}$ & & & & $\mathbf{x}$ & & & $\begin{array}{l}\text { Broccoli sprout homogenate } \\
\text { shake prepared from } 200 \mathrm{~g} \\
\text { sprout (about } 100 \mu \mathrm{mol} \text { of } \mathrm{SF} \\
\text { per dose) or alfalfa sprout } \\
\text { homogenate for control, for } 4 \\
\text { days }\end{array}$ & 42 & $100 \mu \mathrm{mol}$ SF/day (est.) & $1.43(\mathrm{SF})$ & $\begin{array}{l}\text { BSH supplementation increased } \\
\text { live attenuated influenza } \\
\text { virus-induced granzyme B } \\
\text { production in NK cells compared } \\
\text { to control }\end{array}$ & [96] \\
\hline 2016 & Sudini & Asthma & & $\mathrm{x}$ & & & & $\mathrm{x}$ & & & $\begin{array}{l}100 \mathrm{~g} \text { fresh broccoli sprouts } \\
\text { (BS) / } \mathrm{d} \text { or } 100 \mathrm{~g} \text { of alfalfa } \\
\text { sprouts (placebo) } \times 3 \\
\text { consecutive d }\end{array}$ & 40 & $\begin{array}{l}\text { no GR or SF measurements } \\
\text { made or imputed; max poss. } \\
\text { expected to be } 500 \mu \text { mol } \\
\text { GR/d }\end{array}$ & $7.14(\mathrm{GR})$ & $\begin{array}{l}\text { No induction of cytoprotective } \\
\text { antioxidant genes in either PBMCs } \\
\text { or nasal epithelial cells or } \downarrow \\
\text { oxidative stress and inflammatory } \\
\text { markers in urine and serum; no } \\
\text { improved lung function. }\end{array}$ & [95] \\
\hline 2016 & Wise & COPD & $\mathrm{x}$ & & & $\mathrm{x}$ & & & & $\mathrm{x}$ & $\begin{array}{l}\text { SF extracted from broccoli } \\
\text { sprouts }(25 \mu \mathrm{mol} / 150 \mu \mathrm{mol}) \\
\text { daily for four weeks }\end{array}$ & 89 & $25 \mu \mathrm{mol} \mathrm{SF} / \mathrm{d} ; 150 \mu \mathrm{mol} \mathrm{SF} / \mathrm{d}$ & $0.36 \& 2.14(\mathrm{SF})$ & $\begin{array}{l}\text { SF did not stimulate expression of } \\
\text { Nrf2 target genes or have an effect } \\
\text { on levels of other anti-oxidants or } \\
\text { markers of inflammation. }\end{array}$ & [105] \\
\hline
\end{tabular}


Table 1. Cont.

\begin{tabular}{|c|c|c|c|c|c|c|c|c|c|c|c|c|c|c|c|c|}
\hline & & & & 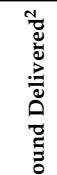 & & & 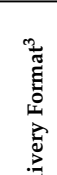 & & $\begin{array}{r}\text { Non } \\
\text { Pr } \\
\text { So }\end{array}$ & $\begin{array}{l}\text { Fresh } \\
\text { duct } \\
\text { irce }\end{array}$ & & & & & & \\
\hline Year $^{1}$ & $\begin{array}{c}\text { First } \\
\text { Author }\end{array}$ & $\begin{array}{c}\text { Study } \\
\text { Population }\end{array}$ & 岕 & త్ & \begin{tabular}{l}
$\sum^{5}$ \\
+ \\
\multirow{2}{*}{}
\end{tabular} & 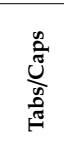 & 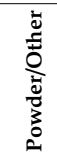 & $\begin{array}{l}\text { 离 } \\
\text { 点 }\end{array}$ & 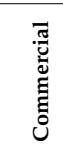 & 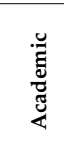 & Treatment $^{5}$ & $\begin{array}{l}\stackrel{2}{z} \\
\frac{0}{2} \\
\text { : } \\
\text { nू }\end{array}$ & $\begin{array}{l}\text { Dose as Reported, } \\
\text { Converted to } \mu \mathrm{mol}^{6}\end{array}$ & $\mu \mathrm{mol} / \mathrm{kg} \mathrm{BW}{ }^{7}$ & Results & Ref \\
\hline 2017 & Axelsson & $\begin{array}{l}\text { Diabetics } \\
\text { (well } \\
\text { regulated, and } \\
\text { dysregulated) }\end{array}$ & & $\mathrm{x}$ & & & $\mathrm{x}$ & & $\mathrm{x}$ & & $5410 \mathrm{ppm}$ of $\mathrm{SF} \times 5 \mathrm{~g} / \mathrm{d}$ & 97 & $153 \mu \mathrm{mol} \mathrm{SF} / \mathrm{d}$ & 2.18 (SF) & $\begin{array}{l}\text { SF reduced fasting blood glucose } \\
\text { (hepatic gluconeogenesis) \& } \\
\text { glycated hemoglobin (HbA1c) in } \\
\text { obese patients with dysregulated } \\
\text { T2D }\end{array}$ & [86] \\
\hline 2017 & Davidson & Osteoarthritis & & $\mathrm{x}$ & & & & $\mathrm{x}$ & & & $\begin{array}{l}100 \mathrm{~g} \text { high glucosinolate }(\mathrm{HG}) \\
\text { broccoli/d x } 14 \mathrm{~d}\end{array}$ & 40 & $180 \mu \mathrm{mol}$ GR/d & 2.57 (GR) & $\begin{array}{l}\text { ITCs detected in synovial fluid of } \\
\text { HG group, but not the low } \\
\text { glucosinolate group. }\end{array}$ & [59] \\
\hline 2017 & Fahey & Healthy & $\mathrm{x}$ & & & $\mathrm{x}$ & $\mathrm{x}$ & & $\mathrm{x}$ & $\mathrm{x}$ & $\begin{array}{l}94.4 \mu \mathrm{mol} \mathrm{SF} / \mathrm{d} \text { or } 200 \mu \mathrm{mol} \\
\alpha \text {-cyclodextrin enrobed SF/d }\end{array}$ & 10 & $94.4 \mu \mathrm{mol} \mathrm{SF} / \mathrm{d}$ & $1.35 \& 2.86$ (SF) & $\begin{array}{l}\text { PK and tolerance of } \alpha \text {-cyclodextrin } \\
\text { enrobed SF (for theoretical } \\
\text { stabilization) was compared to that } \\
\text { of SF along, in the commercial } \\
\text { "stabilized SF" product } \\
\text { Prostaphane" }\end{array}$ & [66] \\
\hline 2018 & Sedlak & Healthy & $\mathrm{x}$ & & & $\mathrm{x}$ & & & & $\mathrm{x}$ & $\begin{array}{l}100 \mu \mathrm{mol} \mathrm{SF} / \mathrm{d} \times 7 \mathrm{~d} \text { taken in } \\
2 \text { gel caps per day }\end{array}$ & 9 & $100 \mu \mathrm{mol} \mathrm{SF} / \mathrm{d}$ & $1.43(\mathrm{SF})$ & $\begin{array}{l}\text { Correlation between blood and } \\
\text { thalamic GSH post- and pre-SF } \\
\text { treatment ratios and a consistent } \\
\text { increase in brain GSH levels ( } 7 \\
\text { Tesla MRI) }\end{array}$ & [81] \\
\hline 2018 & Tahata & Melanoma & $\mathrm{x}$ & & & & $\mathrm{x}$ & & & $x$ & $\begin{array}{l}\text { Broccoli sprout extract-SF } \\
\text { standardized for } 50,100 \text {, or } \\
200 \mu \mathrm{mol} \text { SF for } 28 \text { days }\end{array}$ & 17 & $\begin{array}{l}50 \mu \mathrm{mol} / 100 \mathrm{umol} / 200 \mu \mathrm{mol} \\
\mathrm{SF} / \mathrm{day}\end{array}$ & $\begin{array}{l}0.71 / 1.43 / 2.86 \\
(\mathrm{SF})\end{array}$ & $\begin{array}{l}\text { Oral BSE-SF is well tolerated at } 50, \\
100, \text { and } 200 \mu \mathrm{mol} / \text { day attaining } \\
\text { blood plasma and skin biopsy } \\
\text { levels reasonable for } \\
\text { pharmacodynamic action }\end{array}$ & [104] \\
\hline 2018 & Bent & $\begin{array}{l}\text { Children with } \\
\text { ASD and } \\
\text { related } \\
\text { neurodevelopme } \\
\text { disorders } \\
\end{array}$ & & & $\mathrm{x}$ & & & & $x$ & & $\begin{array}{l}6 \text { to } 15 \text { Avmacol tablets ( } 222 \\
\mu \text { mol GR to } 555 \mu \mathrm{mol} \text { GR) } \\
\text { daily for } 12 \text { weeks, } \\
\text { depending on } \mathrm{BW}\end{array}$ & 15 & $\begin{array}{l}222 \text { umol GR/day - } 555 \text { umol } \\
\text { GR/day }\end{array}$ & $3.17-7.93$ (GR) & $\begin{array}{l}\text { Mean scores on both symptom } \\
\text { measures showed improvements } \\
\text { (decreases) over the study period, } \\
\text { which was correlated with urinary } \\
\text { metabolites }\end{array}$ & [120] \\
\hline 2018 & Housley & Healthy & & & $\mathrm{x}$ & & & $\mathrm{x}$ & & & $\begin{array}{l}\text { fresh broccoli sprouts } \\
\text { (containing } 200 \mu \mathrm{mol} \text { GR) }\end{array}$ & 10 & $200 \mu \mathrm{mol}$ GR/d & 2.86 (GR) & $\begin{array}{l}\text { Untargeted metabolomic screen of } \\
\text { human plasma following } \\
\text { consumption of fresh broccoli } \\
\text { sprouts }\end{array}$ & [137] \\
\hline 2018 & Okunade & Healthy & & $\mathrm{x}$ & $\mathrm{x}$ & & & $\mathbf{x}$ & & & $\begin{array}{l}200 \mathrm{~g} \text { raw, cooked broccoli } \pm \\
1 \mathrm{~g} \text { mustard powder }\end{array}$ & 12 & $\begin{array}{l}\text { 62, 32, or } 257 \mu \mathrm{mol} \text { GR/d } \\
\text { based on conversion of } \\
\text { author's dry wt., to (our) } \\
\text { fresh wt. basis }\end{array}$ & $\begin{array}{l}0.88 / 0.45 / 3.7 \\
(\mathrm{GR})\end{array}$ & $\begin{array}{l}\uparrow \text { urinary SF-NAC when cooked } \\
\text { broccoli consumed with mustard } \\
\text { powder }\end{array}$ & [138] \\
\hline
\end{tabular}


Table 1. Cont.

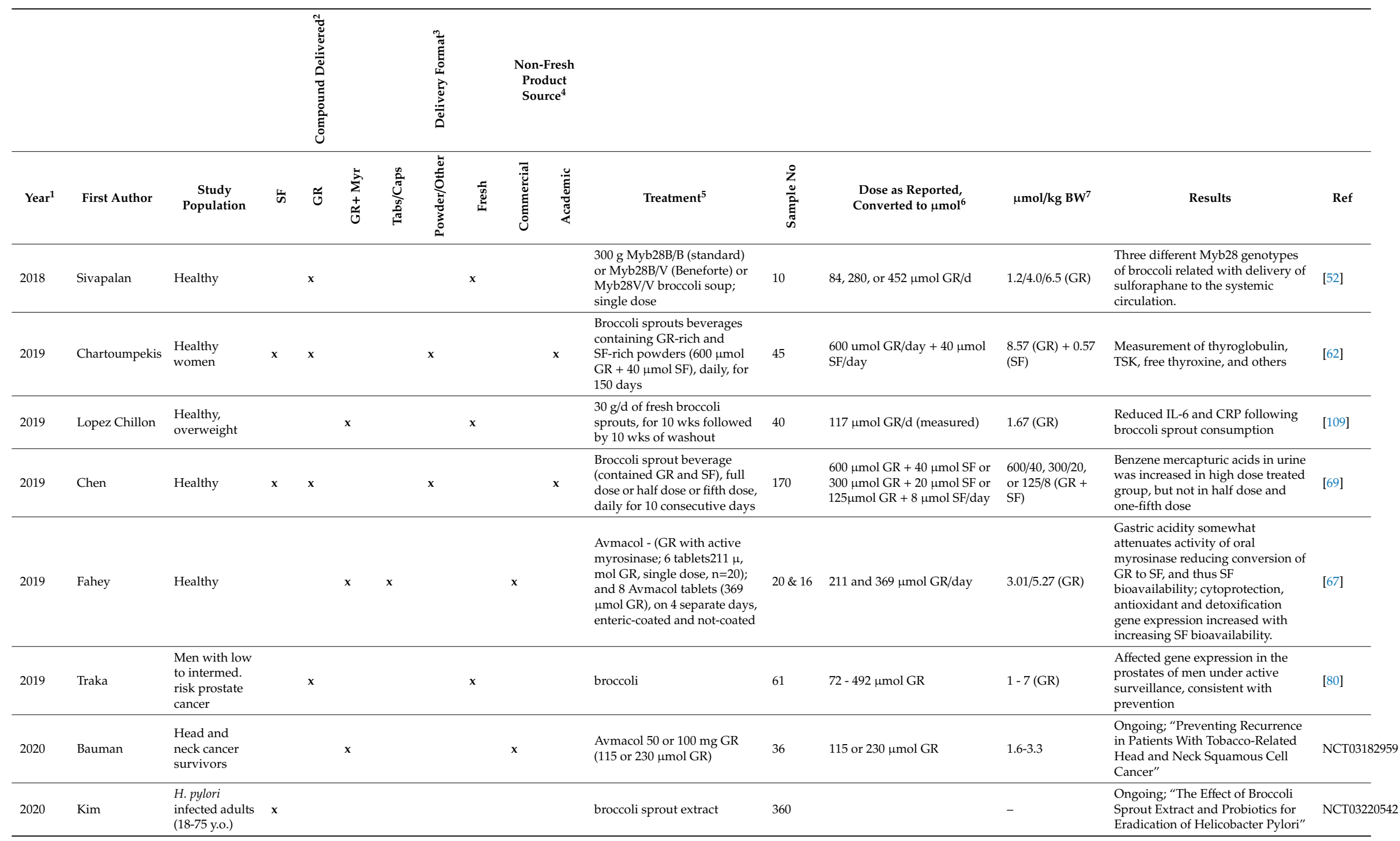


Table 1. Cont.

\begin{tabular}{|c|c|c|c|c|c|c|c|c|c|c|c|c|c|c|c|c|}
\hline & & & & 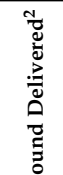 & & & 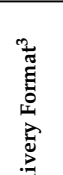 & & $\begin{array}{l}\text { Non } \\
\text { Pro } \\
\text { Sou }\end{array}$ & $\begin{array}{l}\text { resh } \\
\text { uct } \\
\text { ce }^{4}\end{array}$ & & & & & & \\
\hline Year $^{1}$ & $\begin{array}{l}\text { First } \\
\text { Author }\end{array}$ & $\begin{array}{c}\text { Study } \\
\text { Population }\end{array}$ & w & ज̃ & \begin{tabular}{l}
$\sum_{+}^{5}$ \\
+ \\
\multirow{0}{*}{}
\end{tabular} & 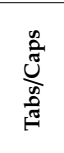 & 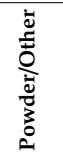 & 离 & 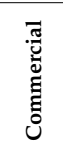 & 若 & Treatment $^{5}$ & 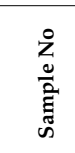 & $\begin{array}{l}\text { Dose as Reported, } \\
\text { Converted to } \mu \mathrm{mol}^{6}\end{array}$ & $\mu \mathrm{mol} / \mathrm{kg} \mathrm{BW}{ }^{7}$ & Results & Ref \\
\hline 2020 & Bauman & Smokers & & & $\mathrm{x}$ & & & & $\mathrm{x}$ & & Avmacol - 4 or 8 tablets/d & 61 & $\begin{array}{l}\text { (our calculation) 138 and } \\
275 \mu \mathrm{mol} \text { GR }\end{array}$ & 2.0/4.0 (GR) & $\begin{array}{l}\text { Ongoing; Decreasing Toxicity in } \\
\text { Heavy Smokers }\end{array}$ & NCT0340223 \\
\hline 2020 & Dickerson & $\begin{array}{l}\text { Adults (18-65 } \\
\text { y.o.) with } \\
\text { schizophrenia }\end{array}$ & & & $\mathrm{x}$ & $\mathrm{x}$ & & & $\mathrm{x}$ & & Avmacol & 64 & $\begin{array}{l}\text { weight-based, about } 1.4 \\
\mu \mathrm{mol} / \mathrm{kg} \mathrm{BW}\end{array}$ & 1.42 (GR) & $\begin{array}{l}\text { Ongoing; amelioration of } \\
\text { symptoms of schizophrenia }\end{array}$ & NCT0281096 \\
\hline 2020 & Hua/Davis & $\begin{array}{l}\text { Children (3-15 } \\
\text { y.o.) on the } \\
\text { autism } \\
\text { spectrum }\end{array}$ & & & $\mathrm{x}$ & $\mathrm{x}$ & & & $\mathrm{x}$ & & Avmacol & 110 & & - & $\begin{array}{l}\text { Ongoing; amelioration of } \\
\text { symptoms of autism spectrum } \\
\text { disorder (ASD) }\end{array}$ & NCT0287911 \\
\hline 2020 & Hua/Davis & $\begin{array}{l}\text { Adults with } \\
1 \text { st episode or } \\
\text { early onset } \\
\text { schizophrenia }\end{array}$ & & & $\mathrm{x}$ & $\mathrm{x}$ & & & $\mathrm{x}$ & & Avmacol & 180 & & - & $\begin{array}{l}\text { Ongoing; amelioration of } \\
\text { symptoms of schizophrenia }\end{array}$ & NCT0288046 \\
\hline 2020 & Johnson & $\begin{array}{l}\text { Young adults } \\
\text { (13-30 y.o.), on } \\
\text { the autism } \\
\text { spectrum }\end{array}$ & & & $x$ & $\mathrm{x}$ & & & $\mathrm{x}$ & & Avmacol & 45 & $\begin{array}{l}\text { weight-based, about } 1.5 \\
\mu \mathrm{mol} / \mathrm{kg} \text { BW }\end{array}$ & 1.47 (GR) & $\begin{array}{l}\text { Ongoing; amelioration of } \\
\text { symptoms of autism spectrum } \\
\text { disorder (ASD) }\end{array}$ & NCT0267705 \\
\hline 2020 & $\mathrm{Li}$ & $\begin{array}{l}\text { Veterans with } \\
\text { allergic } \\
\text { rhinitis }\end{array}$ & $\mathrm{x}$ & $\mathrm{x}$ & & & & & & & broccoli sprout extract & 475 & $\begin{array}{l}\text { Phase } 2 \text { RCT; BSE paired } \\
\text { with fluticasone or normal } \\
\text { saline spray }\end{array}$ & - & $\begin{array}{l}\text { Ongoing; “Effects of Broccoli } \\
\text { Sprout Extract on Allergy Rhinitis” }\end{array}$ & $\begin{array}{l}\text { NCT } \\
0288 \\
5025\end{array}$ \\
\hline 2020 & Politte & $\begin{array}{l}\text { Young men } \\
\text { (13-30 y.o.), on } \\
\text { the autism } \\
\text { spectrum }\end{array}$ & & & $\mathrm{x}$ & $\mathrm{x}$ & & & $\mathrm{x}$ & & Avmacol & 48 & $\begin{array}{l}\text { weight-based, about } 1.4 \\
\mu \mathrm{mol} / \mathrm{kg} \text { BW }\end{array}$ & 1.4 (GR) & $\begin{array}{l}\text { Ongoing; amelioration of } \\
\text { symptoms of autism spectrum } \\
\text { disorder (ASD) }\end{array}$ & $\begin{array}{l}\text { NCT } \\
0290 \\
9959\end{array}$ \\
\hline 2020 & Tex Tech & $\begin{array}{l}\text { Doxirubicin-naii } \\
\text { women with } \\
\text { breast cancer }\end{array}$ & & & $\mathrm{x}$ & & & & $\mathrm{x}$ & & $\begin{array}{l}\text { Avmacol }(2-8 \text { tablets/d) } \times 12 \\
\text { weeks; weight based }\end{array}$ & 70 & $68.8-275 \mu \mathrm{mol} \mathrm{GR}$ & $1-3.9$ (GR) & $\begin{array}{l}\text { Ongoing; "Effects of the SF on } \\
\text { doxorubicin-associated cardiac } \\
\text { dysfunction" }\end{array}$ & $\begin{array}{l}\text { NCT } \\
0393 \\
4905 \\
\end{array}$ \\
\hline 2020 & Wang & $\begin{array}{l}\text { Adults at risk } \\
\text { for psychosis }\end{array}$ & & & $\mathrm{x}$ & $\mathrm{x}$ & & & $\mathrm{x}$ & & $\begin{array}{l}\text { Chinese commercial “GR + } \\
\text { Myros. " supplement } \\
\text { (Zhiyinguosu) }\end{array}$ & 300 & $\begin{array}{l}52 \mathrm{wk} \text {, daily about } 411 \mu \mathrm{mol} \\
\text { GR with active myrosinase }\end{array}$ & 5.9 (GR) & $\begin{array}{l}\text { Ongoing; } 1^{\circ} \text { planned outcome - } \\
\text { conversion to psychosis }\end{array}$ & $\begin{array}{l}\text { NCT } \\
0393 \\
2136 \\
\end{array}$ \\
\hline 2020 & Wu & $\begin{array}{l}\text { 1st episode or } \\
\text { early onset } \\
\text { schizophrenia } \\
\text { (SZ) }\end{array}$ & & & $x$ & & & & $\mathrm{x}$ & & Avmacol & 180 & & - & $\begin{array}{l}\text { Ongoing; "A 6-month Study to } \\
\text { Evaluate SF add-on Effects in } \\
\text { Treatment of SZ" }\end{array}$ & $\begin{array}{l}\text { NCT } \\
0288 \\
0462\end{array}$ \\
\hline
\end{tabular}


Table 1. Cont.

\begin{tabular}{|c|c|c|c|c|c|c|c|c|c|c|c|c|c|c|c|c|}
\hline & & & & 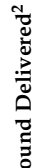 & & & 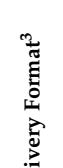 & & $\begin{array}{l}\text { Non- } \\
\text { Pro } \\
\text { Sou }\end{array}$ & & & & & & & \\
\hline Year $^{1}$ & $\begin{array}{l}\text { First } \\
\text { Author }\end{array}$ & $\begin{array}{c}\text { Study } \\
\text { Population }\end{array}$ & $\omega$ & जี & 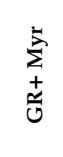 & 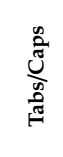 & 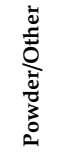 & 矛 & 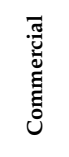 & 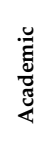 & Treatment ${ }^{5}$ & 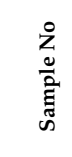 & $\begin{array}{l}\text { Dose as Reported, } \\
\text { Converted to } \mu \mathrm{mol}^{6}\end{array}$ & $\mu \mathrm{mol} / \mathrm{kg} \mathrm{BW}{ }^{7}$ & Results & Ref \\
\hline 2020 & Yuan & $\begin{array}{l}\text { Former } \\
\text { Smokers }\end{array}$ & & & $\mathrm{x}$ & & & & $\mathrm{x}$ & & Avmacol & 72 & $120 \mu \mathrm{mol} 2 \mathrm{x} / \mathrm{d}$ & 3.4 (GR) & $\begin{array}{l}\text { Ongoing; lung cancer prevention } \\
\text { in former smokers }\end{array}$ & $\begin{array}{l}\text { NCT } \\
0323 \\
2138 \\
\end{array}$ \\
\hline 2020 & Zandberg & $\begin{array}{l}\text { Head \& neck } \\
\text { cancer } \\
\text { patients } \\
\text { post-curative } \\
\text { treatment }\end{array}$ & & & $\mathrm{x}$ & $\mathrm{x}$ & & & $\mathrm{x}$ & & $\begin{array}{l}\text { Avmacol; escalating daily } \\
\text { doses, from } 2 \text { to } 4 \text { to } 8 \text { tabs } \\
\text { per day for a month each }\end{array}$ & 36 & 69,138 , or $275 \mu \mathrm{mol} \mathrm{GR}$ & 1/2/3.9 (GR) & Ongoing & $\begin{array}{l}\text { NCT } \\
0326 \\
8993\end{array}$ \\
\hline 2020 & Zimmerman & $\begin{array}{l}\text { Children (3-12 } \\
\text { y.o.), on the } \\
\text { autism } \\
\text { spectrum }\end{array}$ & & & $x$ & $x$ & & & $x$ & & Avmacol & 60 & $\begin{array}{l}\text { weight-based, about } 2.2 \\
\mu \mathrm{mol} / \mathrm{kg} \text { BW }\end{array}$ & $2.2(\mathrm{GR})$ & $\begin{array}{l}\text { Ongoing; amelioration of } \\
\text { symptoms of autism spectrum } \\
\text { disorder }\end{array}$ & $\begin{array}{l}\text { NCT } \\
0256 \\
1481\end{array}$ \\
\hline
\end{tabular}

${ }^{1}$ Year published, if published results exist. In cases where it appears that the trial is well underway and/or when we have queried the P.I., we have included "pending" trials that are listed on clincaltrials.gov. In such cases "year pub'd" is arbitrarily given as 2020. ${ }^{2}$ Compound(s) delivered are either sulforaphane (SF), glucoraphanin (GR) or GR with added, active, myrosinase enzyme (GR $+\mathrm{Myr})^{3}$ Delivery formats are: Tablets or capsules (gelatin or vegan/vegetable gel-caps) - "Tabs/caps"; powders that may be added to juices, water, or other food products - "Powder/Other"; fresh broccoli or broccoli sprouts, either cooked in various ways as indicated, or raw - "Fresh" " When products are commercially supplied, there is reason for concern over use solely of manufacturers' reported compound (GR or SF) titer. Many investigators appropriately measure compound concentration themselves and where we have included studies that do not do so, we have attempted to so note. ${ }^{5}$ As above, we have attempted to note cases where titer is suspect and in some cases we have tested the products used (purchased commercially ourselves, so likely other "lots"), and found them to be vastly different in content or quality, from indications made in the sales literature for those products. Other abbreviations used herein - BSE, broccoli sprout extract; BSP, broccoli sprout powder; GS, glucosinolate; ITC, isothiocyanate; ASD, autism spectrum disorder; SZ schizophrenia; RCT, randomized control trial ${ }^{6}$ Assumptions made in calculations are that if fed homogenized fresh broccoli or broccoli sprouts, they were getting SF and it was in many cases impossible to even guess how much, if any. Thus, if given fresh broccoli or broccoli sprouts and titer not provided in reference, our assumption is that sprout titer was $\leq 5 \mu m o l$ GR/g sprouts, and subjects were ingesting "GR + Myr". ${ }^{7}$ In cases where the authors did not indicate dosage in $\mu \mathrm{mol} / \mathrm{kg}$ body weight (BW), we have made those calculations using the $a$ priori assumption of a $70 \mathrm{~kg}$ BW. 


\section{Challenges Ahead}

\subsection{Plants Versus Discrete Isolates: Foods vs. Supplements}

As an ultimate public health paradigm, eating plants directly, with or without cooking or minimal processing, must be the solution in most of the world. The wealthiest regions can afford supplements as preventive interventions. Attempting to turn a chemopreventive approach into a pharmaceutical strategy would be foolhardy, but to the extent that sulforaphane is proven to have curative or therapeutic properties, this could be a direction in which to turn. From the perspective of designing and conducting clinical studies to demonstrate preventive efficacy, many issues come to bear on the subject. Though we have dealt with them $[65,139,140]$, certain of them bear repeating:

\subsubsection{First}

If it is indeed plant foods that will be the ultimate delivery vehicle, then food companies which will share in an enormous upside to successfully enhanced health-span, must bear some of the costs of conducting these trials. Though much has been made of the size and lobbying muscle of "big pharma", (roughly a trillion dollar industry worldwide), the food sector of the economy in the USA alone is now valued at about $\$ 1.1$ trillion [141].

\subsubsection{Second}

Standardization of dose delivery is extremely difficult when conducting clinical studies with foods. As sulforaphane gains scientific credibility as a preventive phytochemical, the clinical studies aiming to determine how, how much, for how long, and how to deliver and measure it, will by definition grow larger, longer, and more sophisticated. Perhaps there will come a time when foods such as broccoli will be labeled with variety name (e.g., like the maddening little stickers on apples) and glucoraphanin titer to enhance the consumer's ability to make direct health-span purchasing choices. In the meantime, the clinical studies that we have performed with broccoli and broccoli sprouts have already strained the academic system to the breaking point [142]. The food industry needs to step up.

We and others have switched to the use of sulforaphane-containing or sulforaphane-generating supplements as discussed herein. However, the use of commercial supplements is fraught with dangers since there are many poor supplements and many unscrupulous supplement purveyors [143,144]. Robust quality control is essential. Thus, better industry monitoring and regulation, as well as rigorous validation by investigators, of the labeled "doses", is critical. One cannot for the foreseeable future trust that what appears on the label is an accurate representation of "dose" (and sometimes plant entity), and in Table 1 we have indicated clinical studies in which label results have been used rather than making dose measurements prior to or during intervention.

\subsubsection{Third}

There must be clinician buy-in to the concept that "thy food is thy medicine, and thy medicine is thy food". It has been attributed, perhaps fallaciously, to Hippocrates, but regardless of its origin, the physicians who are Hippocrates' intellectual descendants, have not risen to take the bait. They have instead taken the bait of big pharma, hook-line-and-sinker, and it is threatening to sink our economy. Pharmaceuticals most certainly have their place, but we must recruit the physicians in our society, whom people still trust in matters of their critical and preventive care, to more firmly place at least one foot in the dietary side of the aisle.

\subsection{Optimizing the Definition of Dose}

Several key challenges in the design of clinical chemoprevention trials, especially food-based trials, are the selection of the dose, formulation, and dose schedule of the intervention material. Dose schedule is typically delineated by the convenience of a daily schedule and knowledge of the short 
biological half-life of sulforaphane. The other factors are less circumscribed. Selection of dose is complicated by the very different bioavailability of sulforaphane when administered in the precursor form of glucoraphanin and when given as sulforaphane itself, as discussed earlier. Figure 4 summarizes our experiences from four clinical trials conducted in Qidong, China with broccoli-based interventions enriched with glucoraphanin, sulforaphane, or both.

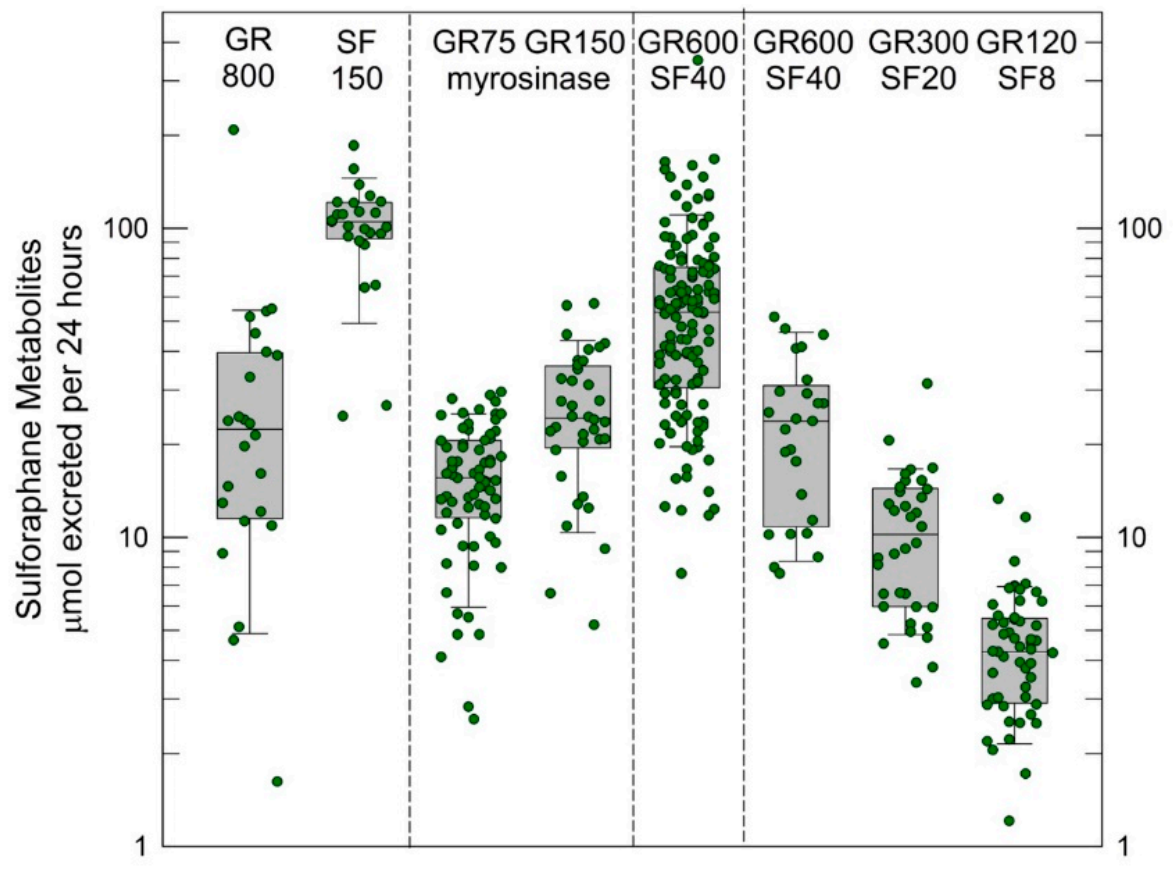

Figure 4. Urinary excretion of sulforaphane metabolites ("internal dose") per $24 \mathrm{~h}$ following an initial dose with different broccoli sprout preparations from intervention studies conducted in Qidong China $[63,77,78]$. All analyses were conducted by isotope dilution mass spectrometry. Values are the sum of sulforaphane, sulforaphane-cysteine and sulforaphane- $N$-acetylcysteine for each participant. Box plots are median and 5\% and 95\% confidence intervals. GR 800 was a beverage prepared from a hot-water extract of 3-day old broccoli sprouts that was lyophilized, and then reconstituted in mango juice and water to deliver $800 \mu$ mole glucoraphanin (GR); SF 150 was the hot-water extract cooled to room temperature, treated with daikon to deliver myrosinase, then lyophilized and later reconstituted in mango juice and water to deliver $150 \mu \mathrm{mol}$ of sulforaphane (SF). GR600 + SF 40 were beverages reconstituted in pineapple juice, lime juice and water from their lyophilized powders to deliver a dose of $600 \mu \mathrm{mol}$ of GR and $40 \mu \mathrm{mol}$ SF. In addition to beverages, a study was conducted with a commercial dietary supplement formulated as tablets constituted from lyophilized broccoli sprouts and finely milled broccoli seeds to provide glucoraphanin $(75$ and $150 \mu \mathrm{mol})$ in the presence of myrosinase.

In a cross-over design study we observed recoveries of excreted sulforaphane metabolites (principally sulforaphane-N-acetylcysteine) to be about $5 \%$ when a glucoraphanin-rich beverage was administered with a range of 1 to $45 \%$ but about $70 \%$ with a much narrow range of inter-individual variation when a sulforaphane-rich beverage was used [68]. Thus, bioavailability changes dramatically as a function of the source material-precursor or bioactive. Some of our subsequent studies used blends of sulforaphane- and glucoraphanin-rich preparations to improve bioavailability together with tolerability and to examine dose-response relationships [69,78]. Higher intake was achieved, but with little impact on inter-individual variability. Formulation, which in turn reflects how broccoli sprout extracts are prepared (e.g., with or without exogenous myrosinase-catalyzed hydrolysis of glucoraphanin), strongly affects bioavailability. Using a dietary supplement formulation of glucoraphanin plus myrosinase (Avmacol ${ }^{\circledR}$ ) in tablet form, we observed a median $20 \%$ bioavailability with greatly dampened inter-individual variability. Fahey et al. [67] have observed approximately 35\% bioavailability with this supplement in a different population. Thus, reporting of administered dose of 
glucoraphanin and/or sulforaphane is a poor measure of the bioavailable/bioactive dose of sulforaphane. As a consequence, we propose that the excreted amount of sulforaphane metabolites (sulforaphane + sulforaphane cysteine-glycine + sulforaphane cysteine + sulforaphane $\mathrm{N}$-acetylcysteine) in urine over $24 \mathrm{~h}$ (2-3 half-lives), which is a measure of "internal dose", provides a more revealing and likely consistent view of the delivery of sulforaphane to study participants. In turn, use of "internal dose" metrics will facilitate optimization of the linkage between formulation, dose, and schedule with determinants of efficacy and, importantly, allow more facile comparisons of results between different clinical trials.

\subsection{Integrating Animal and Clinical Studies}

Epidemiological studies have strongly hinted at beneficial associations between crucifer or more specifically broccoli consumption and mitigation of disease risks. However, it is the animal studies that have provided a robust foundation for the imperative to conduct clinical trials with broccoli, broccoli sprouts and derived-preparations or sulforaphane itself. As summarized in the Supplemental Tables S1-S4, there are a breadth as well as depth of studies describing roles for sulforaphane in the prevention and treatment of diseases in mouse and rat models.

Yet, animal studies have not delivered all that might be expected of them. It is clear from the data presented in Figure 5 that the pre-clinical experimentalists have not thought carefully about the selection of dose (or route) and its relevance to clinical utility. Using oral dosing in mice and rat studies as examples, over two-thirds of the animal studies have used doses that exceed the highest (and bordering on intolerable) doses of sulforaphane used in humans, even after accounting for allometric scaling between rodents and humans. Few studies have included a dose-response; thus, the greater than 4-log spread of doses used in mice appears to be driven by needs for effect reporting in publications rather than optimization of translational science. Authors of this review have contributed to this dose skewing, among many investigators.

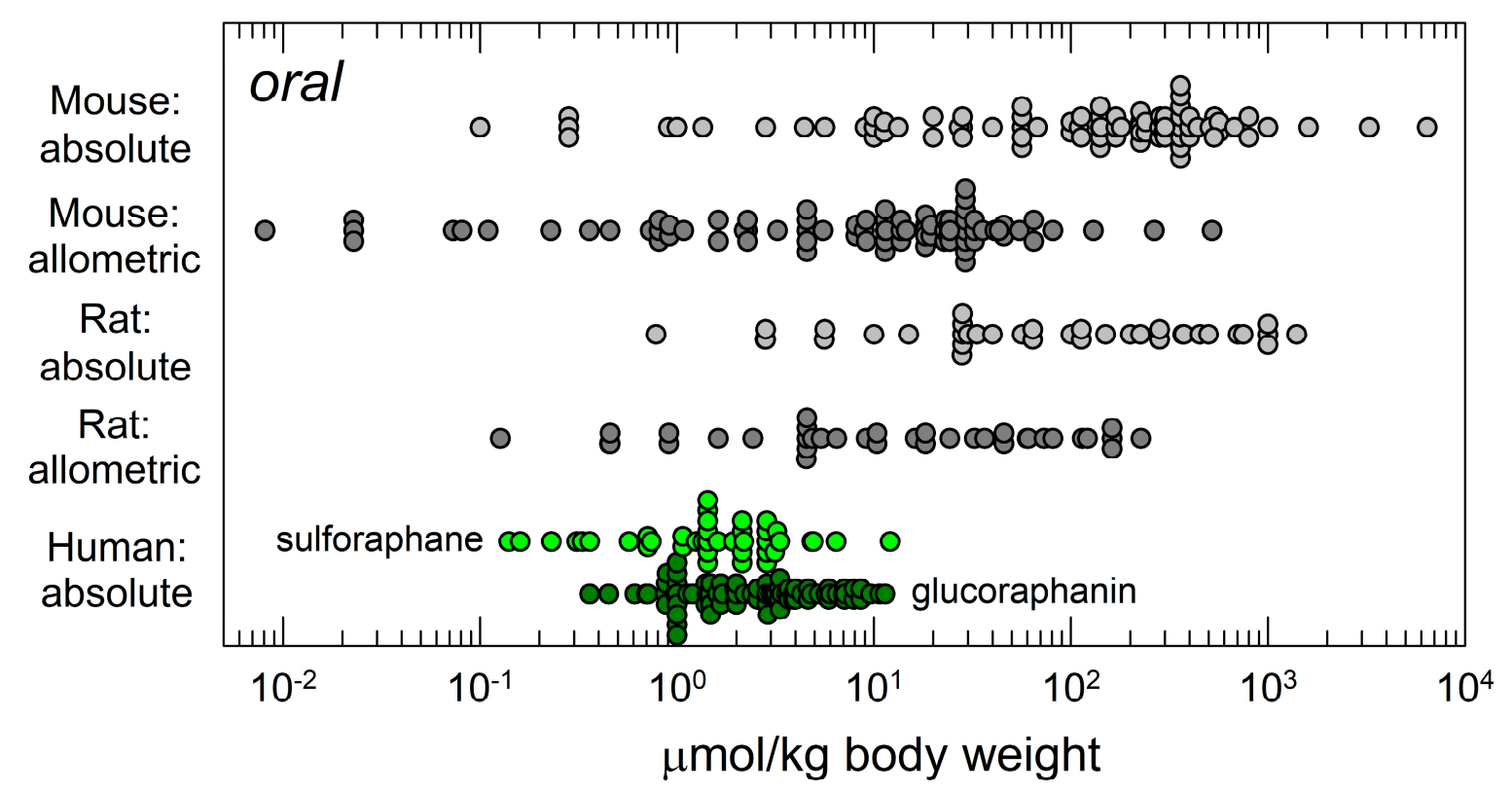

Figure 5. Comparisons of published oral doses of sulforaphane administered to mice or rats and sulforaphane (tablets or sulforaphane-rich broccoli preparations) or glucoraphanin-rich broccoli preparations administered to humans. The allometric scaling of the murine doses uses the correction factor of 0.081 and those for rat doses 0.162 [145]. Human doses were based on an estimate of $70 \mathrm{~kg}$ body weights in each study. 
How were initial doses selected for clinical trials with broccoli-based preparations? Not from any animal studies, which were already in abundance when the first in human studies were conducted. Not from pharmacological studies in rodents to define peak plasma levels, half-lives, metabolic fate or tissue distribution of sulforaphane. Rather, after initial, careful quantitative dose-escalation pharmacokinetic studies by Talalay and colleagues $[26,60,61]$ with crucifers, clinical trialists quickly sought to push doses to the extremes of tolerability by attempting to mask the bitter taste of the simple enriched formulations in order to identify pharmacodynamic action. Only recently have there been attempts to define minimally effective doses in humans - an outcome made possible by the development of consistently formulated, stable, bioavailable broccoli-derived preparations. The disconnect between animal and human studies has been exacerbated because of the public health-based desire (and regulatory-driven need) to conduct the initial human studies with broccoli-based preparations, that in hindsight varied greatly in sulforaphane yield and bioavailability, and the expedient use of pure sulforaphane in most animal studies. Feeding animals lyophilized broccoli or powdered broccoli extracts were likely disfavored because of the need for high percentages within the diet, which could skew overall nutrient uptake. Preparations with stabilized sulforaphane now entering clinical use will close the gap in formulation and could be used to provide more quantitative insights into dose-response [20,102]. Regardless, experimentalists need to now pay close attention to examining efficacy-and underlying mechanisms-using dose and schedule equivalencies to those that are attainable and tolerable in humans-and arguably with oral and not intraperitoneal routes of administration. This notion also extends to in vitro studies, whether in human or animal cell lines, that often report the use of sulforaphane concentrations in far excess of what is likely achievable in human tissues as peak levels, never mind the short biological half-life in vivo that quickly attenuates the duration of the exposure.

\subsection{Better Efficacy Biomarkers}

While there has been substantial progress in the refinement of sourcing and formulation to optimize the pharmacokinetics of broccoli-based preparations now used in clinical trials, there is nonetheless limited information on the factors that contribute to the wide inter-individual variation in pharmacokinetics seen in many clinical trial participants. Host factors (genetic polymorphisms and epigenetics) as well as host-microbiome interactions likely play important roles in this variability. Additionally, there is a striking need to develop rigorous biomarkers of pharmacodynamic action. Better links between purported mechanisms of action delineated in the pre-clinical settings and functional assessments of clinical efficacy are needed to optimize interventions and to better identify those healthy or at-risk groups that might best benefit. With more than 50 papers published on clinical studies with broccoli, glucoraphanin-rich and/or sulforaphane-rich broccoli beverages, powders and dietary supplements, as well as stabilized formulations of sulforaphane, there is ample optimism for disease preventing or mitigating applications to continue evolving. The additional listings of more than 50 proposed/ongoing trials in ClinicalTrials.gov also bears witness to such expectations. Short-term markers of pharmacodynamic actions-likely supported by -omics platforms - are needed to serve as guideposts for rapid deployment of existing and emerging knowledge for the betterment of health using broccoli-based strategies.

Supplementary Materials: The following are available online. Table S1: Summary of literature reporting oral dosing of mice with sulforaphane, Table S2: Summary of literature reporting intraperitoneal dosing of mice with sulforaphane, Table S3: Summary of literature reporting topical administration of sulforaphane to mice, Table S4: Summary of literature reporting oral dosing of rats with sulforaphane.

Author Contributions: All authors contributed to the literature survey, compilation of doses, formulations and outcomes reported, and co-wrote the manuscript.

Funding: This work was supported by the Japan Society for the Promotion of Science [OT 290125], the National Institutes of Health [R35 CA197222], Washington State Andy Hill CARE Fund, The Lewis B. and Dorothy Cullman Foundation, Cancer Research UK [C20953/A18644], and BBSRC [BB/L01923X/1]. 
Acknowledgments: We thank our many colleagues who have contributed to our studies on sulforaphane. Special thanks to Patricia Egner (Johns Hopkins University) for conducting the sulforaphane metabolite measures depicted in Figure 4.

Conflicts of Interest: The authors declare no conflict of interest. The funders had no role in the design of the study; in the collection, analyses, or interpretation of data; in the writing of the manuscript, or in the decision to publish the results.

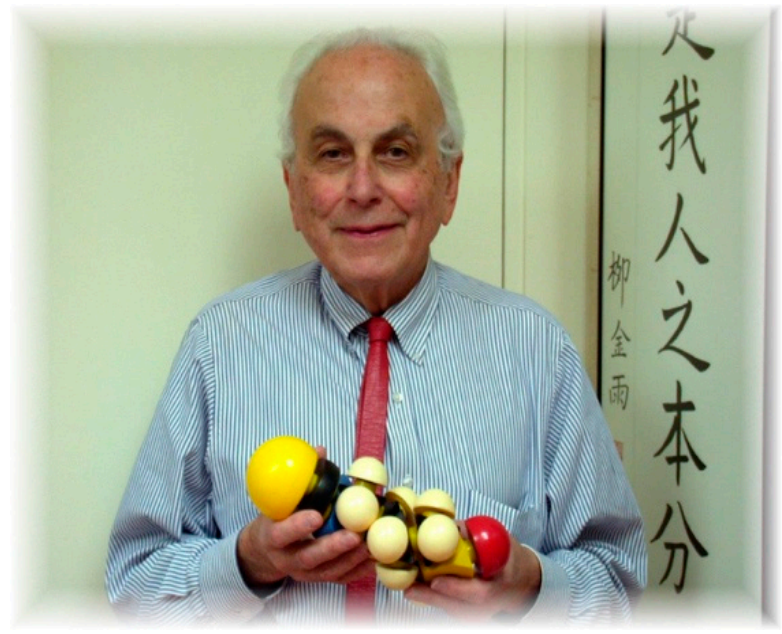

Dedication: The lives and careers of the three senior authors on this review have been affected profoundly by the friendship and mentoring provided by the late Paul Talalay MD (1923-2019). His visionary precept that rigorous, quantitative sciences would serve as the foundation for the discovery, isolation, evaluation, and clinical translation of natural products for disease prevention, especially those isolated from vegetables, has guided the scientific inquiries discussed in this article. He literally planted the seeds for the continuing evolution of broccoli, and specifically sulforaphane, as an effective agent for reducing the burdens of disease in humans as reviewed in his "Reflections" writing in the Journal of Biological Chemistry [146] and as reflected in a literature that now exceeds 3000 papers. His scientific legacy continues to expand and will be nurtured by many.

\section{References}

1. Fahey, J. Brassica: Characteristics and properties. Encycl. Food Health 2016, 1, 469-477.

2. Graham, S.; Dayal, H.; Swanson, M.; Mittelman, A.; Wilkinson, G. Diet in the epidemiology of cancer of the colon and rectum. J. Natl. Cancer Inst. 1978, 61, 709-714. [PubMed]

3. Michaud, D.S.; Spiegelman, D.; Clinton, S.K.; Rimm, E.B.; Willett, W.C.; Giovannucci, E.L. Fruit and vegetable intake and incidence of bladder cancer in a male prospective cohort. J. Natl. Cancer Inst. 1999, 91, 605-613. [CrossRef] [PubMed]

4. Cohen, J.H.; Kristal, A.R.; Stanford, J.L. Fruit and vegetable intakes and prostate cancer risk. J. Natl. Cancer Inst. 2000, 92, 61-68. [CrossRef] [PubMed]

5. Panjwani, A.A.; Liu, H.; Fahey, J.W. Crucifers and related vegetables and supplements for neurologic disorders: What is the evidence? Curr. Opin. Clin. Nutr. Metab. Care 2018, 21, 451-457. [CrossRef]

6. Benedict, A.L.; Mountney, A.; Hurtado, A.; Bryan, K.E.; Schnaar, R.L.; Dinkova-Kostova, A.T.; Talalay, P. Neuroprotective effects of sulforaphane after contusive spinal cord injury. J. Neurotrauma 2012, 29, 2576-2586. [CrossRef] [PubMed]

7. Leone, A.; Diorio, G.; Sexton, W.; Schell, M.; Alexandrow, M.; Fahey, J.W.; Kumar, N.B. Sulforaphane for the chemoprevention of bladder cancer: Molecular mechanism targeted approach. Oncotarget 2017, 8, 35412-35424. [CrossRef]

8. Palliyaguru, D.L.; Yuan, J.M.; Kensler, T.W.; Fahey, J.W. Isothiocyanates: Translating the power of plants to people. Mol. Nutr. Food Res. 2018, 62, e1700965. [CrossRef]

9. Dayalan Naidu, S.; Suzuki, T.; Yamamoto, M.; Fahey, J.W.; Dinkova-Kostova, A.T. Phenethyl isothiocyanate, a dual activator of transcription factors NRF2 and HSF1. Mol. Nutr. Food Res. 2018, 62, e1700908. [CrossRef]

10. Interactive Cancer Risk Matrix. 2019. Available online: https://www.wcrf.org/dietandcancer/interactivecancer-risk-matrix (accessed on 6 October 2019). 
11. Fahey, J.W.; Haristoy, X.; Dolan, P.M.; Kensler, T.W.; Scholtus, I.; Stephenson, K.K.; Talalay, P.; Lozniewski, A. Sulforaphane inhibits extracellular, intracellular, and antibiotic-resistant strains of Helicobacter pylori and prevents benzo[a]pyrene-induced stomach tumors. Proc. Natl. Acad. Sci. USA 2002, 99, 7610-7615. [CrossRef]

12. Fahey, J.W.; Talalay, P. Antioxidant functions of sulforaphane: A potent inducer of Phase II detoxication enzymes. Food Chem. Toxicol. 1999, 37, 973-979. [CrossRef]

13. Zhang, Y.; Talalay, P.; Cho, C.G.; Posner, G.H. A major inducer of anticarcinogenic protective enzymes from broccoli: Isolation and elucidation of structure. Proc. Natl. Acad. Sci. USA 1992, 89, 2399-2403. [CrossRef] [PubMed]

14. Zhang, Y.; Kensler, T.W.; Cho, C.G.; Posner, G.H.; Talalay, P. Anticarcinogenic activities of sulforaphane and structurally related synthetic norbornyl isothiocyanates. Proc. Natl. Acad. Sci. USA 1994, 91, 3147-3150. [CrossRef] [PubMed]

15. Fahey, J.W.; Zhang, Y.; Talalay, P. Broccoli sprouts: An exceptionally rich source of inducers of enzymes that protect against chemical carcinogens. Proc. Natl. Acad. Sci. USA 1997, 94, 10367-10372. [CrossRef] [PubMed]

16. Posner, G.H.; Cho, C.G.; Green, J.V.; Zhang, Y.; Talalay, P. Design and synthesis of bifunctional isothiocyanate analogs of sulforaphane: Correlation between structure and potency as inducers of anticarcinogenic detoxication enzymes. J. Med. Chem. 1994, 37, 170-176. [CrossRef]

17. Fahey, J.W.; Dinkova-Kostova, A.T.; Stephenson, K.K.; Talalay, P. The "Prochaska" microtiter plate bioassay for inducers of NQO1. Methods Enzym. 2004, 382, 243-258.

18. Dinkova-Kostova, A.T.; Fahey, J.W.; Kostov, R.V.; Kensler, T.W. KEAP1 and done? Targeting the NRF2 pathway with sulforaphane. Trends Food Sci. Technol. 2017, 69, 257-269. [CrossRef] [PubMed]

19. Dinkova-Kostova, A.T.; Kostov, R.V. Glucosinolates and isothiocyanates in health and disease. Trends Mol. Med. 2012, 18, 337-347. [CrossRef]

20. Cuadrado, A.; Rojo, A.I.; Wells, G.; Hayes, J.D.; Cousin, S.P.; Rumsey, W.L.; Attucks, O.C.; Franklin, S.; Levonen, A.L.; Kensler, T.W.; et al. Therapeutic targeting of the NRF2 and KEAP1 partnership in chronic diseases. Nat. Rev. Drug Discov. 2019, 18, 295-317. [CrossRef]

21. Jiang, X.; Liu, Y.; Ma, L.X.; Ji, R.; Qu, Y.Q.; Xin, Y.; Lv, G.Y. Chemopreventive activity of sulforaphane. Drug Des. Dev. 2018, 12, 2905-2913. [CrossRef]

22. Zhang, Y.; Tang, L. Discovery and development of sulforaphane as a cancer chemopreventive phytochemical. Acta Pharmacol. Sin. 2007, 28, 1343-1354. [CrossRef] [PubMed]

23. Sonderby, I.E.; Geu-Flores, F.; Halkier, B.A. Biosynthesis of glucosinolates-gene discovery and beyond. Trends Plant. Sci 2010, 15, 283-290. [CrossRef] [PubMed]

24. Mikkelsen, M.D.; Olsen, C.E.; Halkier, B.A. Production of the cancer-preventive glucoraphanin in tobacco. Mol. Plant. 2010, 3, 751-759. [CrossRef] [PubMed]

25. Huseby, S.; Koprivova, A.; Lee, B.R.; Saha, S.; Mithen, R.; Wold, A.B.; Bengtsson, G.B.; Kopriva, S. Diurnal and light regulation of sulphur assimilation and glucosinolate biosynthesis in Arabidopsis. J. Exp. Bot. 2013, 64, 1039-1048. [CrossRef] [PubMed]

26. Shapiro, T.A.; Fahey, J.W.; Wade, K.L.; Stephenson, K.K.; Talalay, P. Human metabolism and excretion of cancer chemoprotective glucosinolates and isothiocyanates of cruciferous vegetables. Cancer Epidemiol. Biomark. Prev. 1998, 7, 1091-1100.

27. Ho, C.L.; Tan, H.Q.; Chua, K.J.; Kang, A.; Lim, K.H.; Ling, K.L.; Yew, W.S.; Lee, Y.S.; Thiery, J.P.; Chang, M.W. Engineered commensal microbes for diet-mediated colorectal-cancer chemoprevention. Nat. Biomed. Eng. 2018, 2, 27-37. [CrossRef] [PubMed]

28. Li, Y.; Kiddle, G.; Bennett, R.N.; Wallsgrove, R.M. Local and systemic changes in glucosinolates in Chinese and European cultivars of oilseed rape (Brassica napus L.) after inoculation with Sclerotinia sclerotiorum (stem rot). Ann. Appl. Biol. 1999, 134, 45-58. [CrossRef]

29. Ishimoto, H.; Fukushi, Y.; Yoshida, T.; Tahara, S. Rhizopus and Fusarium are selected as dominant fungal genera in rhizospheres of Brassicaceae. J. Chem. Ecol. 2000, 26, 2387-2399. [CrossRef]

30. Del Carmen Martinez-Ballesta, M.; Moreno, D.A.; Carvajal, M. The physiological importance of glucosinolates on plant response to abiotic stress in Brassica. Int. J. Mol. Sci. 2013, 14, 11607-11625. [CrossRef] [PubMed]

31. Moreira, X.; Abdala-Roberts, L.; Gols, R.; Francisco, M. Plant domestication decreases both constitutive and induced chemical defences by direct selection against defensive traits. Sci. Rep. 2018, 8, 12678. [CrossRef] [PubMed] 
32. Traka, M.H.; Saha, S.; Huseby, S.; Kopriva, S.; Walley, P.G.; Barker, G.C.; Moore, J.; Mero, G.; van den Bosch, F.; Constant, H.; et al. Genetic regulation of glucoraphanin accumulation in Beneforte broccoli. New Phytol. 2013, 198, 1085-1095. [CrossRef] [PubMed]

33. Urbancsok, J.; Bones, A.M.; Kissen, R. Arabidopsis mutants impaired in glutathione biosynthesis exhibit higher sensitivity towards the glucosinolate hydrolysis product allyl-isothiocyanate. Sci. Rep. 2018, 8, 9809. [CrossRef] [PubMed]

34. Fahey, J.W.; Stephenson, K.K. Cancer chemoprotective effects of cruciferous vegetables. Hortscience 1999, 34, 1159-1163. [CrossRef]

35. Farnham, M.W.; Stephenson, K.K.; Fahey, J.W. The capacity of broccoli to induce a mammalian chemoprotective enzyme varies among inbred lines. J. Amer. Soc. Hort. Sci. 2000, 125, 482-488. [CrossRef]

36. Farnham, M.W.; Wilson, P.E.; Stephenson, K.K.; Fahey, J.W. Genetic and environmental effects on glucosinolate content and chemoprotective potency of broccoli. Plant. Breed. 2004, 123, 60-65. [CrossRef]

37. Farnham, M.W.; Stephenson, K.K.; Fahey, J.W. Glucoraphanin level in broccoli seed is largely determined by genotype. Hortscience 2005, 40, 50-53. [CrossRef]

38. Bachmanov, A.A.; Reed, D.R.; Beauchamp, G.K.; Tordoff, M.G. Food intake, water intake, and drinking spout side preference of 28 mouse strains. Behav. Genet. 2002, 32, 435-443. [CrossRef]

39. Mohammed, A.; Fox, J.T.; Miller, M.S. Cancer Chemoprevention: Preclinical In Vivo Alternate Dosing Strategies to Reduce Drug Toxicities. Toxicol. Sci. 2019, 170, 251-259. [CrossRef]

40. Zhang, Y. The molecular basis that unifies the metabolism, cellular uptake and chemopreventive activities of dietary isothiocyanates. Carcinogenesis 2012, 33, 2-9. [CrossRef]

41. Ramirez, C.N.; Li, W.; Zhang, C.; Wu, R.; Su, S.; Wang, C.; Gao, L.; Yin, R.; Kong, A.N. In vitro-in vivo dose response of ursolic acid, sulforaphane, PEITC, and curcumin in cancer prevention. AAPS J. 2017, 20, 19. [CrossRef]

42. Paunkov, A.; Chartoumpekis, D.V.; Ziros, P.G.; Sykiotis, G.P. A bibliometric review of the Keap1/Nrf2 pathway and its related antioxidant compounds. Antioxidants 2019, 8. [CrossRef] [PubMed]

43. Socala, K.; Nieoczym, D.; Kowalczuk-Vasilev, E.; Wyska, E.; Wlaz, P. Increased seizure susceptibility and other toxicity symptoms following acute sulforaphane treatment in mice. Toxicol. Appl. Pharm. 2017, 326, 43-53. [CrossRef] [PubMed]

44. Poulton, E.J.; Levy, L.; Lampe, J.W.; Shen, D.D.; Tracy, J.; Shuhart, M.C.; Thummel, K.E.; Eaton, D.L. Sulforaphane is not an effective antagonist of the human pregnane X-receptor in vivo. Toxicol. Appl. Pharm. 2013, 266, 122-131. [CrossRef] [PubMed]

45. Shorey, L.E.; Madeen, E.P.; Atwell, L.L.; Ho, E.; Lohr, C.V.; Pereira, C.B.; Dashwood, R.H.; Williams, D.E. Differential modulation of dibenzo[def,p]chrysene transplacental carcinogenesis: Maternal diets rich in indole-3-carbinol versus sulforaphane. Toxicol. Appl. Pharm. 2013, 270, 60-69. [CrossRef]

46. Tao, S.; Rojo de la Vega, M.; Chapman, E.; Ooi, A.; Zhang, D.D. The effects of NRF2 modulation on the initiation and progression of chemically and genetically induced lung cancer. Mol. Carcinog. 2018, 57, 182-192. [CrossRef] [PubMed]

47. Kombairaju, P.; Ma, J.; Thimmulappa, R.K.; Yan, S.G.; Gabrielson, E.; Singh, A.; Biswal, S. Prolonged sulforaphane treatment does not enhance tumorigenesis in oncogenic K-ras and xenograft mouse models of lung cancer. J. Carcinog. 2012, 11, 8.

48. Bheemreddy, R.M.; Jeffery, E.H. The metabolic fate of purified glucoraphanin in F344 rats. J. Agric. Food Chem. 2007, 55, 2861-2866. [CrossRef]

49. Melchini, A.; Traka, M.H. Biological profile of erucin: A new promising anticancer agent from cruciferous vegetables. Toxins 2010, 2, 593-612. [CrossRef]

50. Zhang, Y.; Wade, K.L.; Prestera, T.; Talalay, P. Quantitative determination of isothiocyanates, dithiocarbamates, carbon disulfide, and related thiocarbonyl compounds by cyclocondensation with 1,2-benzenedithiol. Anal. Biochem. 1996, 239, 160-167. [CrossRef]

51. Kerns, M.L.; DePianto, D.; Dinkova-Kostova, A.T.; Talalay, P.; Coulombe, P.A. Reprogramming of keratin biosynthesis by sulforaphane restores skin integrity in epidermolysis bullosa simplex. Proc. Natl. Acad. Sci. USA 2007, 104, 14460-14465. [CrossRef]

52. Sivapalan, T.; Melchini, A.; Saha, S.; Needs, P.W.; Traka, M.H.; Tapp, H.; Dainty, J.R.; Mithen, R.F. Bioavailability of Glucoraphanin and Sulforaphane from High-Glucoraphanin Broccoli. Mol. Nutr. Food Res. 2018, 62, e1700911. [CrossRef] [PubMed] 
53. Gasper, A.V.; Al-Janobi, A.; Smith, J.A.; Bacon, J.R.; Fortun, P.; Atherton, C.; Taylor, M.A.; Hawkey, C.J.; Barrett, D.A.; Mithen, R.F. Glutathione S-transferase M1 polymorphism and metabolism of sulforaphane from standard and high-glucosinolate broccoli. Am. J. Clin. Nutr. 2005, 82, 1283-1291. [CrossRef] [PubMed]

54. Egner, P.A.; Kensler, T.W.; Chen, J.G.; Gange, S.J.; Groopman, J.D.; Friesen, M.D. Quantification of sulforaphane mercapturic acid pathway conjugates in human urine by high-performance liquid chromatography and isotope-dilution tandem mass spectrometry. Chem. Res. Toxicol. 2008, 21, 1991-1996. [CrossRef]

55. Cornblatt, B.S.; Ye, L.; Dinkova-Kostova, A.T.; Erb, M.; Fahey, J.W.; Singh, N.K.; Chen, M.S.; Stierer, T.; Garrett-Mayer, E.; Argani, P.; et al. Preclinical and clinical evaluation of sulforaphane for chemoprevention in the breast. Carcinogenesis 2007, 28, 1485-1490. [CrossRef] [PubMed]

56. Ye, L.; Dinkova-Kostova, A.T.; Wade, K.L.; Zhang, Y.; Shapiro, T.A.; Talalay, P. Quantitative determination of dithiocarbamates in human plasma, serum, erythrocytes and urine: Pharmacokinetics of broccoli sprout isothiocyanates in humans. Clin. Chim. Acta 2002, 316, 43-53. [CrossRef]

57. Atwell, L.L.; Hsu, A.; Wong, C.P.; Stevens, J.F.; Bella, D.; Yu, T.W.; Pereira, C.B.; Lohr, C.V.; Christensen, J.M.; Dashwood, R.H.; et al. Absorption and chemopreventive targets of sulforaphane in humans following consumption of broccoli sprouts or a myrosinase-treated broccoli sprout extract. Mol. Nutr. Food Res. 2015, 59, 424-433. [CrossRef] [PubMed]

58. Zhang, Z.; Garzotto, M.; Davis, E.W., 2nd; Mori, M.; Stoller, W.A.; Farris, P.E.; Wong, C.P.; Beaver, L.M.; Thomas, G.V.; Williams, D.E.; et al. Sulforaphane bioavailability and chemopreventive activity in men presenting for biopsy of the prostate gland: A randomized controlled trial. Nutr. Cancer 2019, 1-14. [CrossRef]

59. Davidson, R.; Gardner, S.; Jupp, O.; Bullough, A.; Butters, S.; Watts, L.; Donell, S.; Traka, M.; Saha, S.; Mithen, R.; et al. Isothiocyanates are detected in human synovial fluid following broccoli consumption and can affect the tissues of the knee joint. Sci. Rep. 2017, 7, 3398. [CrossRef]

60. Shapiro, T.A.; Fahey, J.W.; Wade, K.L.; Stephenson, K.K.; Talalay, P. Chemoprotective glucosinolates and isothiocyanates of broccoli sprouts: Metabolism and excretion in humans. Cancer Epidemiol. Biomark. Prev. 2001, 10, 501-508.

61. Shapiro, T.A.; Fahey, J.W.; Dinkova-Kostova, A.T.; Holtzclaw, W.D.; Stephenson, K.K.; Wade, K.L.; Ye, L.; Talalay, P. Safety, tolerance, and metabolism of broccoli sprout glucosinolates and isothiocyanates: A clinical phase I study. Nutr. Cancer 2006, 55, 53-62. [CrossRef]

62. Chartoumpekis, D.V.; Ziros, P.G.; Chen, J.G.; Groopman, J.D.; Kensler, T.W.; Sykiotis, G.P. Broccoli sprout beverage is safe for thyroid hormonal and autoimmune status: Results of a 12-week randomized trial. Food Chem. Toxicol. 2019, 126, 1-6. [CrossRef] [PubMed]

63. Egner, P.A.; Chen, J.G.; Wang, J.B.; Wu, Y.; Sun, Y.; Lu, J.H.; Zhu, J.; Zhang, Y.H.; Chen, Y.S.; Friesen, M.D.; et al. Bioavailability of Sulforaphane from two broccoli sprout beverages: Results of a short-term, cross-over clinical trial in Qidong, China. Cancer Prev. Res. (Phila) 2011, 4, 384-395. [CrossRef] [PubMed]

64. Li, F.; Hullar, M.A.; Beresford, S.A.; Lampe, J.W. Variation of glucoraphanin metabolism in vivo and ex vivo by human gut bacteria. Br. J. Nutr. 2011, 106, 408-416. [CrossRef] [PubMed]

65. Fahey, J.W.; Wehage, S.L.; Holtzclaw, W.D.; Kensler, T.W.; Egner, P.A.; Shapiro, T.A.; Talalay, P. Protection of humans by plant glucosinolates: Efficiency of conversion of glucosinolates to isothiocyanates by the gastrointestinal microflora. Cancer Prev. Res. (Phila) 2012, 5, 603-611. [CrossRef]

66. Fahey, J.W.; Wade, K.L.; Wehage, S.L.; Holtzclaw, W.D.; Liu, H.; Talalay, P.; Fuchs, E.; Stephenson, K.K. Stabilized sulforaphane for clinical use: Phytochemical delivery efficiency. Mol. Nutr. Food Res. 2017, 61. [CrossRef] [PubMed]

67. Fahey, J.W.; Wade, K.L.; Stephenson, K.K.; Panjwani, A.A.; Liu, H.; Cornblatt, G.; Cornblatt, B.S.; Ownby, S.L.; Fuchs, E.; Holtzclaw, W.D.; et al. Bioavailability of sulforaphane following ingestion of glucoraphanin-rich broccoli sprout and seed extracts with active myrosinase: A pilot study of the effects of proton pump inhibitor administration. Nutrients 2019, 11. [CrossRef]

68. Fahey, J.W.; Holtzclaw, W.D.; Wehage, S.L.; Wade, K.L.; Stephenson, K.K.; Talalay, P. Sulforaphane bioavailability from glucoraphanin-rich broccoli: Control by active endogenous myrosinase. PLoS ONE 2015, 10, e0140963. [CrossRef] [PubMed]

69. Chen, J.G.; Johnson, J.; Egner, P.; Ng, D.; Zhu, J.; Wang, J.B.; Xue, X.F.; Sun, Y.; Zhang, Y.H.; Lu, L.L.; et al. Dose-dependent detoxication of the airborne pollutant benzene in a randomized trial of broccoli sprout beverage in Qidong, China. Am. J. Clin. Nutr. 2019. [CrossRef] [PubMed] 
70. Bogaards, J.J.; Verhagen, H.; Willems, M.I.; van Poppel, G.; van Bladeren, P.J. Consumption of Brussels sprouts results in elevated alpha-class glutathione S-transferase levels in human blood plasma. Carcinogenesis 1994, 15, 1073-1075. [CrossRef]

71. Sreerama, L.; Hedge, M.W.; Sladek, N.E. Identification of a class 3 aldehyde dehydrogenase in human saliva and increased levels of this enzyme, glutathione S-transferases, and DT-diaphorase in the saliva of subjects who continually ingest large quantities of coffee or broccoli. Clin. Cancer Res. 1995, 1, 1153-1163.

72. Bauman, J.E.; Zang, Y.; Sen, M.; Li, C.; Wang, L.; Egner, P.A.; Fahey, J.W.; Normolle, D.P.; Grandis, J.R.; Kensler, T.W.; et al. Prevention of carcinogen-induced oral cancer by sulforaphane. Cancer Prev. Res. (Phila) 2016, 9, 547-557. [CrossRef] [PubMed]

73. Brown, R.H.; Reynolds, C.; Brooker, A.; Talalay, P.; Fahey, J.W. Sulforaphane improves the bronchoprotective response in asthmatics through Nrf2-mediated gene pathways. Respir. Res. 2015, 16, 106. [CrossRef] [PubMed]

74. Doss, J.F.; Jonassaint, J.C.; Garrett, M.E.; Ashley-Koch, A.E.; Telen, M.J.; Chi, J.T. Phase 1 Study of a sulforaphane-containing broccoli sprout homogenate for sickle cell disease. PLoS ONE 2016, 11, e0152895. [CrossRef] [PubMed]

75. Dinkova-Kostova, A.T.; Fahey, J.W.; Wade, K.L.; Jenkins, S.N.; Shapiro, T.A.; Fuchs, E.J.; Kerns, M.L.; Talalay, P. Induction of the phase 2 response in mouse and human skin by sulforaphane-containing broccoli sprout extracts. Cancer Epidemiol Biomark. Prev. 2007, 16, 847-851. [CrossRef]

76. Riedl, M.A.; Saxon, A.; Diaz-Sanchez, D. Oral sulforaphane increases Phase II antioxidant enzymes in the human upper airway. Clin. Immunol. 2009, 130, 244-251. [CrossRef] [PubMed]

77. Kensler, T.W.; Ng, D.; Carmella, S.G.; Chen, M.; Jacobson, L.P.; Munoz, A.; Egner, P.A.; Chen, J.G.; Qian, G.S.; Chen, T.Y.; et al. Modulation of the metabolism of airborne pollutants by glucoraphanin-rich and sulforaphane-rich broccoli sprout beverages in Qidong, China. Carcinogenesis 2012, 33, 101-107. [CrossRef]

78. Egner, P.A.; Chen, J.G.; Zarth, A.T.; Ng, D.K.; Wang, J.B.; Kensler, K.H.; Jacobson, L.P.; Munoz, A.; Johnson, J.L.; Groopman, J.D.; et al. Rapid and sustainable detoxication of airborne pollutants by broccoli sprout beverage: Results of a randomized clinical trial in China. Cancer Prev. Res. (Phila) 2014, 7, 813-823. [CrossRef]

79. Traka, M.; Gasper, A.V.; Melchini, A.; Bacon, J.R.; Needs, P.W.; Frost, V.; Chantry, A.; Jones, A.M.; Ortori, C.A.; Barrett, D.A.; et al. Broccoli consumption interacts with GSTM1 to perturb oncogenic signalling pathways in the prostate. PloS ONE 2008, 3, e2568. [CrossRef]

80. Traka, M.H.; Melchini, A.; Coode-Bate, J.; Al Kadhi, O.; Saha, S.; Defernez, M.; Troncoso-Rey, P.; Kibblewhite, H.; O'Neill, C.M.; Bernuzzi, F.; et al. Transcriptional changes in prostate of men on active surveillance after a 12-mo glucoraphanin-rich broccoli intervention-results from the Effect of Sulforaphane on prostate CAncer PrEvention (ESCAPE) randomized controlled trial. Am. J. Clin. Nutr. 2019, 109, 1133-1144. [CrossRef]

81. Sedlak, T.W.; Nucifora, L.G.; Koga, M.; Shaffer, L.S.; Higgs, C.; Tanaka, T.; Wang, A.M.; Coughlin, J.M.; Barker, P.B.; Fahey, J.W.; et al. Sulforaphane augments glutathione and influences brain metabolites in human subjects: A clinical pilot study. Mol. Neuropsychiatry 2018, 3, 214-222. [CrossRef]

82. Armah, C.N.; Traka, M.H.; Dainty, J.R.; Defernez, M.; Janssens, A.; Leung, W.; Doleman, J.F.; Potter, J.F.; Mithen, R.F. A diet rich in high-glucoraphanin broccoli interacts with genotype to reduce discordance in plasma metabolite profiles by modulating mitochondrial function. Am. J. Clin. Nutr. 2013, 98, 712-722. [CrossRef] [PubMed]

83. Talalay, P.; Fahey, J.W.; Healy, Z.R.; Wehage, S.L.; Benedict, A.L.; Min, C.; Dinkova-Kostova, A.T. Sulforaphane mobilizes cellular defenses that protect skin against damage by UV radiation. Proc. Natl. Acad. Sci. USA 2007, 104, 17500-17505. [CrossRef] [PubMed]

84. Knatko, E.V.; Ibbotson, S.H.; Zhang, Y.; Higgins, M.; Fahey, J.W.; Talalay, P.; Dawe, R.S.; Ferguson, J.; Huang, J.T.; Clarke, R.; et al. Nrf2 activation protects against solar-simulated ultraviolet radiation in mice and humans. Cancer Prev Res. (Phila) 2015, 8, 475-486. [CrossRef] [PubMed]

85. Armah, C.N.; Derdemezis, C.; Traka, M.H.; Dainty, J.R.; Doleman, J.F.; Saha, S.; Leung, W.; Potter, J.F.; Lovegrove, J.A.; Mithen, R.F. Diet rich in high glucoraphanin broccoli reduces plasma LDL cholesterol: Evidence from randomised controlled trials. Mol. Nutr. Food Res. 2015, 59, 918-926. [CrossRef] [PubMed]

86. Axelsson, A.S.; Tubbs, E.; Mecham, B.; Chacko, S.; Nenonen, H.A.; Tang, Y.; Fahey, J.W.; Derry, J.M.J.; Wollheim, C.B.; Wierup, N.; et al. Sulforaphane reduces hepatic glucose production and improves glucose control in patients with type 2 diabetes. Sci. Transl. Med. 2017, 9. [CrossRef] [PubMed] 
87. Singh, K.; Connors, S.L.; Macklin, E.A.; Smith, K.D.; Fahey, J.W.; Talalay, P.; Zimmerman, A.W. Sulforaphane treatment of autism spectrum disorder (ASD). Proc. Natl. Acad. Sci. USA 2014, 111, 15550-15555. [CrossRef]

88. Chen, J.; Zhu, J.; Wang, G.; Groopman, J.D.; Kensler, T.W. Qidong: A crucible for studies on liver cancer etiology and prevention. Cancer Biol. Med. 2019, 16, 24-37.

89. Egner, P.A.; Wang, J.B.; Zhu, Y.R.; Jacobson, L.P.; Ng, D.; Munoz, A.; Fahey, J.W.; Chen, J.G.; Chen, T.Y.; Qian, G.S.; et al. Prevention of liver cancer in Qidong, China: Lessons from aflatoxin biomarker studies. Prog. Chem. 2013, 25, 1454-1461.

90. Kensler, T.W.; Chen, J.G.; Egner, P.A.; Fahey, J.W.; Jacobson, L.P.; Stephenson, K.K.; Ye, L.; Coady, J.L.; Wang, J.B.; Wu, Y.; et al. Effects of glucosinolate-rich broccoli sprouts on urinary levels of aflatoxin-DNA adducts and phenanthrene tetraols in a randomized clinical trial in He Zuo township, Qidong, People's Republic of China. Cancer Epidemiol Biomark. Prev. 2005, 14, 2605-2613. [CrossRef]

91. Heber, D.; Li, Z.; Garcia-Lloret, M.; Wong, A.M.; Lee, T.Y.; Thames, G.; Krak, M.; Zhang, Y.; Nel, A. Sulforaphane-rich broccoli sprout extract attenuates nasal allergic response to diesel exhaust particles. Food Funct. 2014, 5, 35-41. [CrossRef]

92. Noah, T.L.; Zhang, H.; Zhou, H.; Glista-Baker, E.; Muller, L.; Bauer, R.N.; Meyer, M.; Murphy, P.C.; Jones, S.; Letang, B.; et al. Effect of broccoli sprouts on nasal response to live attenuated influenza virus in smokers: A randomized, double-blind study. PLoS ONE 2014, 9, e98671. [CrossRef] [PubMed]

93. Healy, Z.R.; Lee, N.H.; Gao, X.; Goldring, M.B.; Talalay, P.; Kensler, T.W.; Konstantopoulos, K. Divergent responses of chondrocytes and endothelial cells to shear stress: Cross-talk among COX-2, the phase 2 response, and apoptosis. Proc. Natl. Acad. Sci. USA 2005, 102, 14010-14015. [CrossRef] [PubMed]

94. Meyer, M.; Kesic, M.J.; Clarke, J.; Ho, E.; Simmen, R.C.; Diaz-Sanchez, D.; Noah, T.L.; Jaspers, I. Sulforaphane induces SLPI secretion in the nasal mucosa. Respir. Med. 2013, 107, 472-475. [CrossRef] [PubMed]

95. Sudini, K.; Diette, G.B.; Breysse, P.N.; McCormack, M.C.; Bull, D.; Biswal, S.; Zhai, S.; Brereton, N.; Peng, R.D.; Matsui, E.C. A randomized controlled trial of the effect of broccoli sprouts on antioxidant gene expression and airway inflammation in asthmatics. J. Allergy Clin. Immunol. Pr. 2016, 4, 932-940. [CrossRef] [PubMed]

96. Muller, L.; Meyer, M.; Bauer, R.N.; Zhou, H.; Zhang, H.; Jones, S.; Robinette, C.; Noah, T.L.; Jaspers, I. Effect of broccoli sprouts and live attenuated influenza virus on peripheral blood natural killer cells: A randomized, double-blind study. PLoS ONE 2016, 11, e0147742. [CrossRef] [PubMed]

97. Duran, C.G.; Burbank, A.J.; Mills, K.H.; Duckworth, H.R.; Aleman, M.M.; Kesic, M.J.; Peden, D.B.; Pan, Y.; Zhou, H.; Hernandez, M.L. A proof-of-concept clinical study examining the NRF2 activator sulforaphane against neutrophilic airway inflammation. Respir. Res. 2016, 17, 89. [CrossRef]

98. Atwell, L.L.; Zhang, Z.; Mori, M.; Farris, P.; Vetto, J.T.; Naik, A.M.; Oh, K.Y.; Thuillier, P.; Ho, E.; Shannon, J. Sulforaphane bioavailability and chemopreventive activity in women scheduled for breast biopsy. Cancer Prev. Res. (Phila) 2015, 8, 1184-1191. [CrossRef] [PubMed]

99. Riso, P.; Martini, D.; Visioli, F.; Martinetti, A.; Porrini, M. Effect of broccoli intake on markers related to oxidative stress and cancer risk in healthy smokers and nonsmokers. Nutr. Cancer 2009, 61, 232-237. [CrossRef]

100. Gasper, A.V.; Traka, M.; Bacon, J.R.; Smith, J.A.; Taylor, M.A.; Hawkey, C.J.; Barrett, D.A.; Mithen, R.F. Consuming broccoli does not induce genes associated with xenobiotic metabolism and cell cycle control in human gastric mucosa. J. Nutr. 2007, 137, 1718-1724. [CrossRef]

101. Walters, D.G.; Young, P.J.; Agus, C.; Knize, M.G.; Boobis, A.R.; Gooderham, N.J.; Lake, B.G. Cruciferous vegetable consumption alters the metabolism of the dietary carcinogen 2-amino-1-methyl-6-phenylimidazo [4,5-b]pyridine (PhIP) in humans. Carcinogenesis 2004, 25, 1659-1669. [CrossRef]

102. Cipolla, B.G.; Mandron, E.; Lefort, J.M.; Coadou, Y.; Della Negra, E.; Corbel, L.; Le Scodan, R.; Azzouzi, A.R.; Mottet, N. Effect of sulforaphane in men with biochemical recurrence after radical prostatectomy. Cancer Prev Res. (Phila) 2015, 8, 712-719. [CrossRef]

103. Alumkal, J.J.; Slottke, R.; Schwartzman, J.; Cherala, G.; Munar, M.; Graff, J.N.; Beer, T.M.; Ryan, C.W.; Koop, D.R.; Gibbs, A.; et al. A phase II study of sulforaphane-rich broccoli sprout extracts in men with recurrent prostate cancer. Invest. New Drugs 2015, 33, 480-489. [CrossRef] [PubMed]

104. Tahata, S.; Singh, S.V.; Lin, Y.; Hahm, E.R.; Beumer, J.H.; Christner, S.M.; Rao, U.N.; Sander, C.; Tarhini, A.A.; Tawbi, H.; et al. Evaluation of biodistribution of sulforaphane after administration of oral broccoli sprout extract in melanoma patients with multiple atypical nevi. Cancer Prev. Res. (Phila) 2018, 11, 429-438. [CrossRef] [PubMed] 
105. Wise, R.A.; Holbrook, J.T.; Criner, G.; Sethi, S.; Rayapudi, S.; Sudini, K.R.; Sugar, E.A.; Burke, A.; Thimmulappa, R.; Singh, A.; et al. Lack of effect of oral sulforaphane administration on Nrf2 expression in COPD: A randomized, double-blind, placebo controlled trial. PLoS ONE 2016, 11, e0163716. [CrossRef]

106. Sidhaye, V.K.; Holbrook, J.T.; Burke, A.; Sudini, K.R.; Sethi, S.; Criner, G.J.; Fahey, J.W.; Berenson, C.S.; Jacobs, M.R.; Thimmulappa, R.; et al. Compartmentalization of anti-oxidant and anti-inflammatory gene expression in current and former smokers with COPD. Respir. Res. 2019, 20, 190. [CrossRef] [PubMed]

107. Murashima, M.; Watanabe, S.; Zhuo, X.G.; Uehara, M.; Kurashige, A. Phase 1 study of multiple biomarkers for metabolism and oxidative stress after one-week intake of broccoli sprouts. Biofactors 2004, 22, 271-275. [CrossRef]

108. Christiansen, B.; Bellostas Muguerza, N.; Petersen, A.M.; Kveiborg, B.; Madsen, C.R.; Thomas, H.; Ihlemann, N.; Sorensen, J.C.; Kober, L.; Sorensen, H.; et al. Ingestion of broccoli sprouts does not improve endothelial function in humans with hypertension. PLoS ONE 2010, 5, e12461. [CrossRef] [PubMed]

109. Lopez-Chillon, M.T.; Carazo-Diaz, C.; Prieto-Merino, D.; Zafrilla, P.; Moreno, D.A.; Villano, D. Effects of long-term consumption of broccoli sprouts on inflammatory markers in overweight subjects. Clin. Nutr. 2019, 38, 745-752. [CrossRef]

110. Mirmiran, P.; Bahadoran, Z.; Hosseinpanah, F.; Keyzad, A.; Azizi, F. Effects of broccoli sprout with high sulforaphane concentration on inflammatory markers in type 2 diabetic patients: A randomized double-blind placebo-controlled clinical trial. J. Funct. Foods 2012, 4, 837-841. [CrossRef]

111. Bahadoran, Z.; Mirmiran, P.; Hosseinpanah, F.; Hedayati, M.; Hosseinpour-Niazi, S.; Azizi, F. Broccoli sprouts reduce oxidative stress in type 2 diabetes: A randomized double-blind clinical trial. Eur. J. Clin. Nutr. 2011, 65, 972-977. [CrossRef]

112. Bahadoran, Z.; Tohidi, M.; Nazeri, P.; Mehran, M.; Azizi, F.; Mirmiran, P. Effect of broccoli sprouts on insulin resistance in type 2 diabetic patients: A randomized double-blind clinical trial. Int. J. Food Sci. Nutr. 2012, 63, 767-771. [CrossRef] [PubMed]

113. Healy, Z.R.; Liu, H.; Holtzclaw, W.D.; Talalay, P. Inactivation of tautomerase activity of macrophage migration inhibitory factor by sulforaphane: A potential biomarker for anti-inflammatory intervention. Cancer Epidemiol. Biomark. Prev. 2011, 20, 1516-1523. [CrossRef] [PubMed]

114. Ushida, Y.S.H.; Yanaka, A. Low-dose of the sulforaphane precursor glucoraphanin as a dietary supplement induces chemoprotective enzymes in humans. Food Nutr. Sci. 2015, 6, 62147. [CrossRef]

115. Galan, M.V.; Kishan, A.A.; Silverman, A.L. Oral broccoli sprouts for the treatment of Helicobacter pylori infection: A preliminary report. Dig. Dis. Sci. 2004, 49, 1088-1090. [CrossRef] [PubMed]

116. Yanaka, A.; Fahey, J.W.; Fukumoto, A.; Nakayama, M.; Inoue, S.; Zhang, S.; Tauchi, M.; Suzuki, H.; Hyodo, I.; Yamamoto, M. Dietary sulforaphane-rich broccoli sprouts reduce colonization and attenuate gastritis in Helicobacter pylori-infected mice and humans. Cancer Prev. Res. (Phila) 2009, 2, 353-360. [CrossRef]

117. Bahadoran, Z.; Mirmiran, P.; Yeganeh, M.Z.; Hosseinpanah, F.; Zojaji, H.; Azizi, F. Complementary and alternative medicinal effects of broccoli sprouts powder on Helicobacter pylori eradication rate in type 2 diabetic patients: A randomized clinical trial. J. Funct. Foods 2014, 7, 390-397. [CrossRef]

118. Kikuchi, M.; Ushida, Y.; Shiozawa, H.; Umeda, R.; Tsuruya, K.; Aoki, Y.; Suganuma, H.; Nishizaki, Y. Sulforaphane- rich broccoli sprout extract improves hepatic abnormalities in male subjects. World J. Gastroenterol. 2015, 21, 12457-12467. [CrossRef]

119. Lynch, R.; Diggins, E.L.; Connors, S.L.; Zimmerman, A.W.; Singh, K.; Liu, H.; Talalay, P.; Fahey, J.W. Sulforaphane from broccoli reduces symptoms of autism: A follow-up case series from a randomized double-blind study. Glob. Adv. Health Med. 2017, 6, 2164957X17735826. [CrossRef]

120. Bent, S.; Lawton, B.; Warren, T.; Widjaja, F.; Dang, K.; Fahey, J.W.; Cornblatt, B.; Kinchen, J.M.; Delucchi, K.; Hendren, R.L. Identification of urinary metabolites that correlate with clinical improvements in children with autism treated with sulforaphane from broccoli. Mol. Autism. 2018, 9, 35. [CrossRef]

121. Matile, P. The mustard oil bomb - compartmentation of the myrosinase system. Biochem. Physiol. Pfl. 1980, 175, 722-731. [CrossRef]

122. Fahey, J.W.; Wade, K.L.; Stephenson, K.K.; Shi, Y.; Liu, H.; Panjwani, A.A.; Warrick, C.R.; Olson, M.E. A strategy to deliver precise oral doses of the glucosinolates or isothiocyanates from moringa oleifera leaves for use in clinical studies. Nutrients 2019, 11. [CrossRef] [PubMed]

123. Bierwirth, J.E.; Oftedal, K.N.; Civille, G.V.; Fahey, J.W. Flavor misattribution: A novel approach to improving compliance and blinding in food-based clinical interventions. NFS J. 2015, 1, 24-30. [CrossRef] 
124. Conaway, C.C.; Getahun, S.M.; Liebes, L.L.; Pusateri, D.J.; Topham, D.K.; Botero-Omary, M.; Chung, F.L. Disposition of glucosinolates and sulforaphane in humans after ingestion of steamed and fresh broccoli. Nutr. Cancer 2000, 38, 168-178. [CrossRef] [PubMed]

125. Myzak, M.C.; Tong, P.; Dashwood, W.M.; Dashwood, R.H.; Ho, E. Sulforaphane retards the growth of human PC-3 xenografts and inhibits HDAC activity in human subjects. Exp. Biol Med. (Maywood) 2007, 232, 227-234. [PubMed]

126. Rungapamestry, V.; Duncan, A.J.; Fuller, Z.; Ratcliffe, B. Effect of meal composition and cooking duration on the fate of sulforaphane following consumption of broccoli by healthy human subjects. Br. J. Nutr. 2007, 97, 644-652. [CrossRef] [PubMed]

127. Vermeulen, M.; Klopping-Ketelaars, I.W.; van den Berg, R.; Vaes, W.H. Bioavailability and kinetics of sulforaphane in humans after consumption of cooked versus raw broccoli. J. Agric. Food Chem. 2008, 56, 10505-10509. [CrossRef] [PubMed]

128. Hanlon, N.; Coldham, N.; Gielbert, A.; Sauer, M.J.; Ioannides, C. Repeated intake of broccoli does not lead to higher plasma levels of sulforaphane in human volunteers. Cancer Lett. 2009, 284, 15-20. [CrossRef] [PubMed]

129. Clarke, J.D.; Riedl, K.; Bella, D.; Schwartz, S.J.; Stevens, J.F.; Ho, E. Comparison of isothiocyanate metabolite levels and histone deacetylase activity in human subjects consuming broccoli sprouts or broccoli supplement. J. Agric. Food Chem. 2011, 59, 10955-10963. [CrossRef]

130. Hauder, J.; Winkler, S.; Bub, A.; Rufer, C.E.; Pignitter, M.; Somoza, V. LC-MS/MS quantification of sulforaphane and indole-3-carbinol metabolites in human plasma and urine after dietary intake of selenium-fortified broccoli. J. Agric. Food Chem. 2011, 59, 8047-8057. [CrossRef] [PubMed]

131. Cramer, J.M.; Teran-Garcia, M.; Jeffery, E.H. Enhancing sulforaphane absorption and excretion in healthy men through the combined consumption of fresh broccoli sprouts and a glucoraphanin-rich powder. Br. J. Nutr. 2012, 107, 1333-1338. [CrossRef]

132. Saha, S.; Hollands, W.; Teucher, B.; Needs, P.W.; Narbad, A.; Ortori, C.A.; Barrett, D.A.; Rossiter, J.T.; Mithen, R.F.; Kroon, P.A. Isothiocyanate concentrations and interconversion of sulforaphane to erucin in human subjects after consumption of commercial frozen broccoli compared to fresh broccoli. Mol. Nutr. Food Res. 2012, 56, 1906-1916. [CrossRef] [PubMed]

133. Baier, S.R.; Zbasnik, R.; Schlegel, V.; Zempleni, J. Off-target effects of sulforaphane include the derepression of long terminal repeats through histone acetylation events. J. Nutr. Biochem. 2014, 25, 665-668. [CrossRef]

134. Chang, Y.W.; Jang, J.Y.; Kim, Y.H.; Kim, J.W.; Shim, J.J. The effects of broccoli sprout extract containing sulforaphane on lipid peroxidation and helicobacter pylori infection in the gastric mucosa. Gut. Liver 2015, 9, 486-493. [CrossRef] [PubMed]

135. Medina, S.; Dominguez-Perles, R.; Moreno, D.A.; Garcia-Viguera, C.; Ferreres, F.; Gil, J.I.; Gil-Izquierdo, A. The intake of broccoli sprouts modulates the inflammatory and vascular prostanoids but not the oxidative stress-related isoprostanes in healthy humans. Food Chem. 2015, 173, 1187-1194. [CrossRef] [PubMed]

136. Shiina, A.; Kanahara, N.; Sasaki, T.; Oda, Y.; Hashimoto, T.; Hasegawa, T.; Yoshida, T.; Iyo, M.; Hashimoto, K. An open study of sulforaphane-rich broccoli sprout extract in patients with schizophrenia. Clin. Psychopharmacol. Neurosci. 2015, 13, 62-67. [CrossRef] [PubMed]

137. Housley, L.; Magana, A.A.; Hsu, A.; Beaver, L.M.; Wong, C.P.; Stevens, J.F.; Choi, J.; Jiang, Y.; Bella, D.; Williams, D.E.; et al. Untargeted metabolomic screen reveals changes in human plasma metabolite profiles following consumption of fresh broccoli sprouts. Mol. Nutr. Food Res. 2018, 62, e1700665. [CrossRef] [PubMed]

138. Okunade, O.; Niranjan, K.; Ghawi, S.K.; Kuhnle, G.; Methven, L. Supplementation of the diet by exogenous myrosinase via mustard seeds to increase the bioavailability of sulforaphane in healthy human subjects after the consumption of cooked broccoli. Mol. Nutr. Food Res. 2018, 62, e1700980. [CrossRef] [PubMed]

139. Fahey, J.W.; Kensler, T.W. Role of dietary supplements/nutraceuticals in chemoprevention through induction of cytoprotective enzymes. Chem. Res. Toxicol. 2007, 20, 572-576. [CrossRef]

140. Fahey, J.W.; Kensler, T.W. Frugal medicine: Health-span extension through green chemoprevention. Am. Med. Assoc. Virtual. Mentor. 2013, 15, 311-318.

141. Value added to GDP by agriculture and related industries, 2007-2017. 2019.

142. Fahey, J.W.; Talalay, P.; Kensler, T.W. Notes from the field: "Green" chemoprevention as frugal medicine. Cancer Prev Res. 2012, 5, 179-188. [CrossRef]

143. Talalay, P.; Talalay, P. The importance of using scientific principles in the development of medicinal agents from plants. Acad Med. 2001, 76, 238-247. [CrossRef] [PubMed] 
144. Kapoor, A.; Sharfstein, J.M. Breaking the gridlock: Regulation of dietary supplements in the United States. Drug Test. Anal. 2016, 8, 424-430. [CrossRef] [PubMed]

145. Nair, A.B.; Jacob, S. A simple practice guide for dose conversion between animals and human. J. Basic. Clin. Pharm. 2016, 7, 27-31. [CrossRef] [PubMed]

146. Talalay, P. A fascination with enzymes: The journey not the arrival matters. J. Biol. Chem. 2005, 280, 28829-28847. [CrossRef] [PubMed]

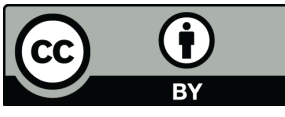

(C) 2019 by the authors. Licensee MDPI, Basel, Switzerland. This article is an open access article distributed under the terms and conditions of the Creative Commons Attribution (CC BY) license (http://creativecommons.org/licenses/by/4.0/). 